\title{
Mass movement deposits in the 3.6 Ma sediment record of Lake El'gygytgyn, Far East Russian Arctic
}

\author{
M. A. Sauerbrey ${ }^{1}$, O. Juschus ${ }^{2}$, A. C. Gebhardt ${ }^{3}$, V. Wennrich ${ }^{1}$, N. R. Nowaczyk ${ }^{4}$, and M. Melles ${ }^{1}$ \\ ${ }^{1}$ Institute of Geology and Mineralogy, University of Cologne, Zuelpicher Str. 49a, 50674 Cologne, Germany \\ ${ }^{2}$ Eberswalde University of Sustainable Development, Faculty of Landscape Management and Nature Conservation, \\ Eberswalde, Germany \\ ${ }^{3}$ Alfred Wegener Institute for Polar and Marine Research, Bremerhaven, Germany \\ ${ }^{4}$ Helmholtz Centre Potsdam, GFZ German Research Centre for Geosciences, Potsdam, Germany
}

Correspondence to: M. A. Sauerbrey (maaret.sauerbrey@gmail.com)

Received: 20 December 2012 - Published in Clim. Past Discuss.: 23 January 2013

Revised: 3 July 2013 - Accepted: 9 July 2013 - Published: 16 August 2013

\begin{abstract}
This paper focuses on the characterization and genesis of mass movement deposits (MMDs) in the Quaternary and Pliocene sediments of Lake El'gygytgyn, Far East Russian Arctic. Three partly overlapping holes were drilled into the $320 \mathrm{~m}$ long sediment record at International Continental Scientific Drilling Program (ICDP) Site 5011-1 in the lake basin, recovering the Quaternary almost completely, and the Pliocene down to 3.6 Ma with $52 \%$ recovery. Mass movement deposits were investigated in all three cores, based on macroscopical core descriptions, radiographic images, highresolution magnetic susceptibility and gamma-ray density. Five different types of MMDs were identified: turbidites, grain-flow deposits, debrites, slumps and slides. These are formed by transitional mass movement processes, and thus can be co-generic. An initial slope failure is thought to transform into a debris flow that deforms frontal sediments, partly disintegrates and dilutes into a turbidity flow. Turbidites are by far the most frequent MMD type in the lake center. They occur throughout the record in all pelagic sedimentary facies, but they are thinner in facies formed during cold climate conditions. All other MMDs, by contrast, incise exclusively the pelagic facies deposited during warm climates. In the $123 \mathrm{~m}$ thick Quaternary composite sediment record 230 mass movement events are identified, comprising $33 \%$ of the sediment length. Turbidites contribute $93 \%$ of the number of Quaternary MMDs, but only 35\% of their thickness. In the Pliocene sediments between 123 and $320 \mathrm{~m}, 181$ additional mass movement deposits are identified, which constitute $\sim 33 \%$ of the recovered sediments. The mean recurrence interval for MMDs is 11 and $5 \mathrm{ka}$ in the Quaternary and Pliocene, respectively.
\end{abstract}

\section{Introduction}

Lacustrine sediment records are an important archive for the reconstruction of environmental and climatic changes. Pelagic sediments, settled continuously on a lake floor from allochthonous and autochthonous supply, are widely used in such reconstructions. Mass movement events, in contrast, can transport significant amounts of sediment in lacustrine or marine basins in very short time periods (minutes to hours). They are potentially erosive, which causes a threat to the quality and continuity of the sediment record subject to paleoenvironmental and paleoclimatological studies. Identification of mass movement deposits (MMD) and their effects on the pelagic sedimentation is thus of crucial importance for the successful interpretation of the pelagic record.

Basins with sharp shelf breaks dividing a lateral slope and a flat lake floor are typical settings for mass movements. This type of relief is found in fjords, fjord-type lakes and in tectonically or volcanically formed lakes (Sturm and Matter, 1978; Bøe et al., 2004; Schnellmann et al., 2005; Gebhardt et al., 2011) as well as in impact crater lakes (Nolan and Brigham-Grette, 2007; Shanahan et al., 2006). Adequate sediment input is one of the most important prerequisites for the initiation of slope failure, and can also control the frequency of such events.

Mass movements do not only have the potential to hamper the paleoenvironmental signal but can also be used for evaluating the frequency and magnitude of these short-lived events and their triggering mechanisms, such as climatic impacts and human or tectonic activities, as well as correlation of parallel cores. For instance, Osleger et al. (2009) 
reported a connection between storminess and turbidite deposition in Lake Tahoe (USA). St-Onge et al. (2004), Blass et al. (2005) and Guyard et al. (2007) differentiated between flood-induced and slump-generated turbidites in Saguenay Fjord (Canada), Lake Sils (Switzerland) and Lake Bramant (France), respectively. Strasser et al. (2006), Monecke et al. (2007) and Schnellmann et al. (2007) have assessed the earthquake history in Swiss lakes based on the occurrence of MMDs. Turbidites can also be deposited through human impact, such as damming (Lake Mead; Twichell et al., 2005). In addition, changes in lake level have been discovered to control turbidite deposition, for example in Lake Bosumtwi (Shanahan et al., 2006).

In spring 2009 the international El'gygytgyn Drilling Project recovered the first generally continuous sedimentary record from the terrestrial Arctic that covers the entire Quaternary and penetrates further into the mid- and late Pliocene (Melles et al., 2011, 2012; Brigham-Grette et al., 2013). The drill cores from Lake El'gygytgyn, northeastern Russia, provide a key record for paleoclimatic reconstruction in the Arctic. However, from large alluvial fans in the northern and western lake catchment, prograding deltas on the western lake shore, and steep lake slopes down to currently $170 \mathrm{~m}$ water depth (Nolan and Brigham-Grette, 2007), it can be expected that the pelagic sedimentation in Lake El'gygytgyn was irregularly influenced by mass movements. This was confirmed already by the first pilot core PG1351, taken in spring 1998 from the central part of Lake El'gygytgyn, in which occasional thin, normally graded beds were discovered and interpreted as possible turbidites (Melles et al., 2007).

Seismic studies, performed during the summers of 2000 and 2003 (Gebhardt et al., 2006, 2013; Niessen et al., 2007), revealed thick, stacked, chaotic to acoustically transparent seismic units interpreted as debris flow deposits reaching down to depths below ca. $167 \mathrm{~m}$ below lake floor. These deposits were further investigated with high-resolution $3.5 \mathrm{kHz}$ sediment echosounding that revealed the abundance of these deposits at the lake slopes (Fig. 1c). There they have proximal thicknesses of $>20 \mathrm{~m}$ and reach the lake center only occasionally, where they have thicknesses up to 3-4 m between well-layered sediments. Erosive debris flow deposits are located proximally, while non-erosive MMDs were identified also in the lake center (Niessen et al., 2007). In 2003, one of the MMDs discovered by $3.5 \mathrm{kHz}$ echosounder data was sampled by two cores (Lz1039 and Lz1041) in order to study its characteristics and influence on the pelagic sedimentation in Lake El'gygytgyn (Juschus et al., 2009). Detailed investigation of these cores, as well as another $16 \mathrm{~m}$ long core from the lake center (Lz1024), revealed that the acoustically transparent seismic unit consists of a basal debris flow deposit (debrite according to Gani, 2004), which is directly overlain by a grain-flow deposit of wider distribution and further by a deposit settled from a suspension cloud (turbidite) that presumably covers wide areas of the lake floor. While both the debrite and the grain-flow deposit have caused erosion of about $1 \mathrm{~m}$ of sediments previously accumulated on the lower slope, the more recent turbidites in the lake center were at least not associated with significant erosion according to radiocarbon dating of the bracketing pelagic sediments. In the pilot core taken at the lake center (Lz1024), a total of 26 turbidites and three grain-flow deposits were accumulated (Juschus et al., 2009) during the past $350 \mathrm{ka}$ (Frank et al., 2012; Nowaczyk et al., 2013), while debris flows did not reach the coring location during this period.

In this paper, the MMDs occurring in the entire $3.6 \mathrm{Ma}$ sediment record in central Lake El'gygytgyn, recovered in spring 2009 by the El'gygytgyn Drilling Project, are identified, characterized and classified. In addition, we present the correlation of the MMDs between the drill cores and pilot core Lz1024 (Juschus et al., 2009), as well as a chronological catalogue of the Quaternary and mid- to late Pliocene MMDs in Lake El'gygytgyn. We also compare the occurrence of MMDs to different pelagic facies and climate conditions. Based on our findings, the processes influencing the mass movement evolution in Lake El'gygytgyn are discussed.

\section{Prerequisite site information}

Lake El'gygytgyn $\left(67^{\circ} 30^{\prime} \mathrm{N}, 172^{\circ} 5^{\prime} \mathrm{E}\right)$, formed after a meteorite impact 3.58 $\pm 0.04 \mathrm{Ma}$ ago (Layer, 2000), is situated in the Far East Russian Arctic, $100 \mathrm{~km}$ north of the Arctic Circle (Fig. 1a). The diameter of the lake is $12 \mathrm{~km}$ and its surface lies $492 \mathrm{~m}$ a.s.l. (Fig. 1b). The most prominent feature of the catchment area of $293 \mathrm{~km}^{2}$ (lake $110 \mathrm{~km}^{2}$ ) is an alluvial plain in the west and north that consists of multiple fans (Schwamborn et al., 2012). The outflow, Enmyvaam River, exits to the southeast of Lake El'gygytgyn. Approximately 50 inlet streams drain into the lake. Gravel bars at the shoreline block many of them, and direct inflow is thus prohibited during the snow-free summer season (Nolan and BrighamGrette, 2007). Characteristic to the lake is its shallow shelf $(<10 \mathrm{~m})$ that is mostly $<100 \mathrm{~m}$ wide, with the exception of the southern and southeastern part of the lake, where it widens to $\sim 1 \mathrm{~km}$. The slopes are steep in a flat-bottomed, bowl-shaped basin with water depths of up to $170 \mathrm{~m}$. The steepest slopes are in the northern and eastern part of the basin, with general angles between 15 and $30^{\circ}$ and a maximum of more than $40^{\circ}$ on the eastern shore, whereas they are more gently inclined with generally $5-15^{\circ}$ on the southern and western shores (Nolan and Brigham-Grette, 2007).

The circular-shaped impact crater has a diameter of $18 \mathrm{~km}$ and was formed in Cretaceous volcanic rocks, such as rhyolitic and dacitic lavas, tuffs and ignimbrites as well as andesites and tuffs of andesitic composition (Gurov and Koeberl, 2004). The highlands at the crater rim today have heights between 50 and $430 \mathrm{~m}$ above lake level. According to the reconstruction of the initial crater depth by Gurov and 

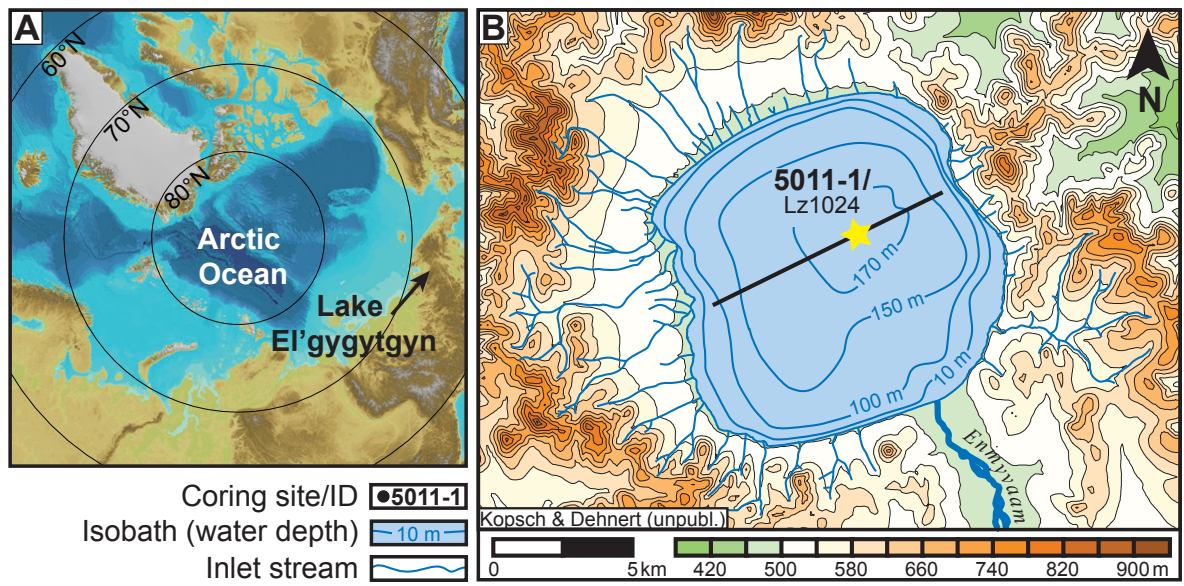

Isobath (water depth)

Inlet stream
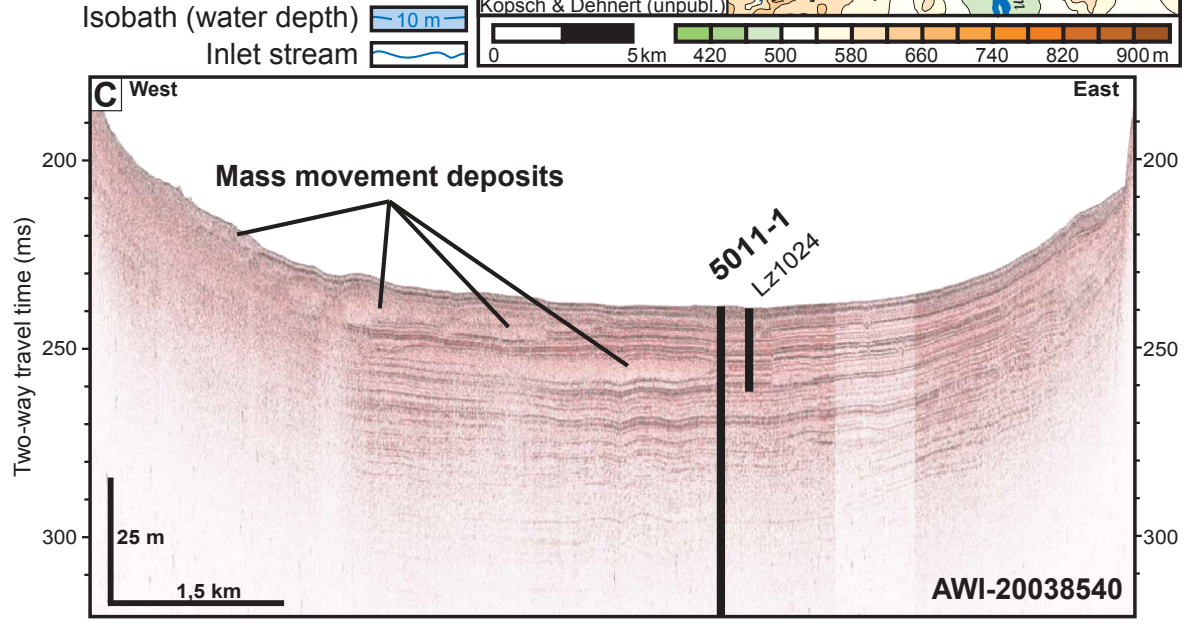

Fig. 1. (A) Location of Lake El'gygytgyn in northeastern Russia. (B) Position of the drill site 5011-1, pilot core Lz1024 and seismic profile (black line) AWI-20038540. Digital elevation model is after Kopsch (2005) and lake bathymetry after Belyi (2001). (C) Sediment echosounder profile AWI-20038540 $(3.5 \mathrm{kHz})$ in a WSW-ENE direction crossing the coring site and showing multiple mass movement deposits (MMDs) as acoustically transparent units on the western slope and lake floor.

Gurova (1981) and Feldman et al. (1980), the crater rim has been eroded by approximately 400 to $500 \mathrm{~m}$.

Lake El'gygytgyn is surrounded by major thrust faults on three sides (west, east and southwest). The lake is situated in the southern end of the Malo-Chauns volcano-tectonic graben structure, while a major thrust fault reaches the southeastern corner of the lake (Belyi and Raikevich, 1994; Stone et al., 2009). In the southeastern catchment, a mercury survey of the soil air revealed elevated $\mathrm{Hg}$ values, indicating ongoing activity of the fault system (Fedorov and Kupolov, 2005). Prior to the 1950s the network of seismograph stations was poor in northeastern Russia, and hence historical seismic data cover only the last ca. $60 \mathrm{yr}$ (Fujita et al., 2009). Between 1960 and 2010 two earthquakes were recorded at distances to the lake of 99 and $66 \mathrm{~km}$, respectively (International Seismological Centre, 2011). These earthquakes shook with a magnitude of 4.2 and 4.4 in 1999 and 1967, respectively. Additional evidence of neotectonic activity was provided by seismic surveys in 2000 and 2003 that revealed small faults within the sediment column that might be related to the central uplift structure of the impact crater (Niessen et al., 2007).
The faults reach to a depth that corresponds roughly to marine isotope stage (MIS) 6.

Geomorphologic investigations in the area have revealed that the closest traces of glaciations are $40 \mathrm{~km}$ away in the Anadyr Highland, and no traces of glacial influence were found within the lake catchment (Glushkova and Smirnov, 2005a, 2007). Lake level has fluctuated during the past, with the highest preserved terrace at 35 to $40 \mathrm{~m}$ above present lake level formed presumably during the Middle Pleistocene (Glushkova and Smirnov, 2007). In addition, terraces at 911 and $3-5 \mathrm{~m}$ above lake level date back to late Pleistocene and Late Glacial times, respectively (Glushkova and Smirnov, 2005b, 2007; Schwamborn et al., 2008). BrighamGrette et al. (2005) reported of a terrace $10 \mathrm{~m}$ below the present lake level, which represents a lake-level lowstand during the Last Glacial Maximum (Juschus et al., 2011). On the northern shore, several pebble bars mark a gradual lake-level drop of $4 \mathrm{~m}$ during the Holocene (Schwamborn et al., 2008). In general, high lake levels have been correlated to warm climate conditions, while lower lake levels are 
presumed to have formed during cooler periods (Juschus et al., 2011).

Presently, Lake El'gygytgyn is situated within the continuous permafrost zone. Its catchment has been influenced by permafrost conditions presumably since the late Pliocene (Glushkova and Smirnov, 2007). Permafrost largely influences weathering and sedimentation processes in the catchment, resulting in an active layer, whose thickness varies between 0.4 to $0.8 \mathrm{~m}$ depending on the grain size and organic content of the sediment (Schwamborn et al., 2008, 2012).

Sediment is transported to the lake through fluvial and aeolian transport as well as by gravitative mass movement processes (Juschus et al., 2005; Fedorov et al., 2013; Francke et al., 2013). Even though the number of inlet streams is high, their sediment discharge to the lake is rather small. All inlet streams transport an estimated $350 \mathrm{t}$ of sediment into the lake annually, almost exclusively during spring and summer. Only ca. $1 \%$ of this is discharged through the outlet Enmyvaam River (Fedorov et al., 2013). Fluvial sediment discharge is presently reduced by permafrost since the ground is still frozen when the snow melts (Nolan and BrighamGrette, 2007). Sediment transport is concentrated to a very short melting period, when even coarse-grained material can be transported to the coastal zone forming sandy and gravelly fans reaching hundred meters onto the lake ice (Fedorov et al., 2013). During snow-free summers, gravel bars at the shoreline of several inlet streams today form lagoons, which trap fine-grained sediment, and thus hinder suspension flow into the lake (Nolan and Brigham-Grette, 2007). Considerable lake-level rises may breach the lagoons, thus transporting coarse-grained material into the lake that may result in mass movement processes (Fedorov et al., 2013). Aeolian transport, in contrast, has not been very significant in present conditions or during the Quaternary (Fedorov et al., 2013; Francke et al., 2013).

Pelagic sedimentation in Lake El'gygytgyn is fine grained (Francke et al., 2013). It can be divided into four major facies, which sensitively reflect different climate conditions (Melles et al., 2011, 2012; Brigham-Grette et al., 2013; Gebhardt et al., 2013). During colder climate stages of the Quaternary, under perennial lake ice, dark gray, finely laminated silt and clay are deposited (facies A). The dominant facies (facies B) contributes $79 \%$ of the Quaternary pelagic sediment record (Melles et al., 2012) and is also widespread in the Pliocene sediments (Brigham-Grette et al., 2013). Facies $\mathrm{B}$ is characterized by olive gray to brownish, massive to faintly banded silt, deposited during relatively warm climate conditions under a semipermanent ice cover. Peak warm climate, such as during marine isotope stages (MIS) 11.3 and 31, is reflected by laminated, reddish-brown silt and high amounts of biogenic silica (facies C) (Melles et al., 2011, 2012; Vogel et al., 2013). Facies D consists of grayish laminated silt and clay with occasional greenish or reddish hues that grade upwards. In contrast to laminated facies A, laminae of facies $D$ are thicker (up to $1 \mathrm{~cm}$ ) and have a higher clay content. This facies only occurs in the Pliocene sediments, and is interpreted as repeated pulses of fluvial input and lack of bioturbation (Brigham-Grette et al., 2013). A fifth facies (E) was identified at the bottom of the lacustrine record overlying the impact breccia. This facies consists of clay, silt and interbedded thin to medium thick fine sand beds that are gray to reddish-brown in color. Occasional thin brecciated intervals, possibly caused by dewatering or short-term desiccation events, are characteristic (Brigham-Grette et al., 2013). Facies E represents the phase after the impact, initial lake filling and the first lacustrine deposition (Raschke et al., 2013; Gebhardt et al., 2013; Brigham-Grette et al., 2013). Over the course of the lake history, sedimentation rates have significantly decreased. During the first ca. $300 \mathrm{ka}$ after the impact, the average sedimentation rate accounted for $44.5 \mathrm{~cm} \mathrm{ka}^{-1}$, and dropped to 15 and $4.7 \mathrm{~cm} \mathrm{ka}^{-1}$ during the remaining Pliocene and the Quaternary, respectively (Haltia and Nowaczyk, 2013; Nowaczyk et al., 2013).

\section{Methods}

Drilling operations of the El'gygytgyn Drilling Project were carried out during winter and spring 2009. Drilling included three holes from the lake ice at International Continental Scientific Drilling Program (ICDP) Site 5011-1 in the central, deepest part of the lake (Fig. 1b; Melles et al., 2011). In holes 5011-1A and 5011-1B, sediment depths of 147 and $112 \mathrm{~m}$ were reached, with recoveries of 92 and $98 \%$, respectively. Hole 5011-1C was drilled from $100 \mathrm{~m}$ down to $517 \mathrm{~m}$, passing the boundary between lake sediments and impact rocks at $320 \mathrm{~m}$. Down to ca. $150 \mathrm{~m}$ and in the lowermost $40 \mathrm{~m}$ of the lake sediment record the recovery was nearly $100 \%$, but in between it was rather poor, leading to a total recovery of $52 \%$ of the lacustrine sediments of hole 5011-1C. Potential reasons for the low core recovery between 150 and $277 \mathrm{~m}$ are technical problems (loss of tools) and the occurrence of coarser (sandy and gravelly) sediments (Melles et al., 2011).

Directly after core opening at the University of Cologne, the core halves were imaged with a GEOTEK line scanner (MSCL CIS Logger, Geotek Ltd.) and measured for their magnetic susceptibility with a point sensor at a resolution of $1 \mathrm{~mm}$ (SCL2.3 Logger, GFZ Potsdam). Based on the macroscopic core description, focusing on grain size, color and sediment structures, sedimentary units were determined, including MMDs. Subsequently the elemental composition was measured and radiographs were obtained on the core halves with an ITRAX core scanner (Cox Analytics) in resolutions of $2 \mathrm{~mm}$ and $200 \mu \mathrm{m}$, respectively, and gamma-ray density measurements were performed at Alfred Wegener Institute in Bremerhaven, Germany, with an MSCL core logger (Geotek Ltd.). For a more detailed description of the drilling operations and core processing, see Melles et al. (2011, 2012), Francke et al. (2013), Gebhardt et al. (2013) or Wennrich et al. (2013b). 
Comparison of the drill cores to the pilot core (Lz1024) revealed that cores 5011-1A and $1 \mathrm{~B}$ start at 5.67 and $6.28 \mathrm{~m}$, respectively (Nowaczyk et al., 2013). The information concerning the 10 uppermost mass movement events above the depth of $5.67 \mathrm{~m}$ is therefore derived from the pilot core described by Juschus et al. (2009). For the comparison and correlation of the mass movement events in each drill hole, we use corrected field depths (cfd), where the difference between the assumed and true field depth is corrected. To enable the comparison of mass movement events to other papers dealing with paleoenvironmental proxies, the events are also presented in composite depths (cd). Below $150 \mathrm{~m}$ only composite depth is used since there is only one core (5011-1C). Even though all mass movement events were given a depth in the core composite, all events thicker than $5 \mathrm{~cm}$ were excluded from the age model of the pelagic sediment record (Melles et al., 2012; Nowaczyk et al., 2013). The age-depth model for the core composite from ICDP site 5011-1 is based on paleomagnetic data (Haltia and Nowaczyk, 2013) and tuning of paleoenvironmental proxies (FTIRS-BSi, $\mathrm{Si} / \mathrm{Ti}$, magnetic susceptibility, TOC, pollen) to variations in the global marine oxygen isotope stack and local insolation (Nowaczyk et al., 2013). Ages of the MMDs were calculated from the sedimentation rates derived from the age-depth model for the pelagic sediments in between.

\section{Characteristics and genesis of mass movement deposits}

Normal pelagic sedimentation in the Lake El'gygytgyn sequence is interrupted by at least eight volcanic ash layers and frequent MMDs. The identification and classification of MMDs used in this paper is based on macroscopic core descriptions on core halves and radiographs, their comparison in parallel cores, and their magnetic susceptibilities and gamma-ray densities. The MMDs in Lake El'gygytgyn can be divided into five different types, based on their individual sedimentological characteristics. Due to new findings in deeper core sections, the terminology used by Juschus et al. (2009) for the uppermost $16 \mathrm{~m}$ in Lake El'gygytgyn had to be extended and modified. Figure 2 provides an overview of the recovered MMDs at ICDP Site 5011-1 in central Lake El'gygytgyn.

\subsection{Turbidites (T)}

Turbidites always show clear normal grading (Fig. 3) and sharp boundaries to the underlying sediment, which makes them easy to distinguish from the pelagic facies. In some cases, the fining upward is very gradual, with diffuse grainsize boundaries. In most cases, however, a stepwise fining upward occurs, with clear intra-bed boundaries between single grain-size classes. This is more evident in the core description than in the radiographs. Grain sizes vary between sand and clay. The different sediment fractions can readily be identified based on their color: the basal sand unit is often dark gray (Munsell color $5 \mathrm{Y} 4 / 1,2.5 \mathrm{Y} 4 / 1$ to N4) and sometimes dark grayish brown $(5 \mathrm{Y} 4 / 2)$, the silty middle unit is slightly lighter dark gray, gray or grayish brown $(5 \mathrm{Y} 4 / 1,5 \mathrm{Y} 5 / 1,2.5 \mathrm{Y} 5 / 2)$ and the clayey top unit is lighter gray $(5 \mathrm{Y} 5 / 1$ to $6 / 1)$, grayish brown $(2.5 \mathrm{Y} 5 / 2)$ or olive gray (5Y 5/2). Especially in the lowermost part of the sediment record the clayey top is often greenish grey (e.g., 10Y 5/1). Radiographs reveal that some thicker turbidites are faintly laminated in the basal sand and coarse silt units. The upper boundaries of thick turbidites are sometimes concealed by a fairly homogenous but slightly darker (2.5Y 5/1-5/2) unit, which appears to be bioturbated. Greenish remnants of redox layers (10Y $5 / 1$ to $5 \mathrm{GY} 4 / 1$ ) can also occur in this unit. However, radiographs as well as magnetic susceptibility and density measurements reveal the grading of this unit (Fig. 3). Magnetic susceptibility is high in the sandy and silty units of turbidites and declines towards the clayey top unit. When redox layer remnants are preserved in the top unit, magnetic susceptibility values slightly increase. Density can be high or low in the sandy basal unit $\left(1.3-1.6 \mathrm{~g} \mathrm{~cm}^{-3}\right)$ and is high in the silty unit $\left(1.5-1.8 \mathrm{~g} \mathrm{~cm}^{-3}\right)$, whereas it decreases towards the clayey top, where it reaches a minimum $\left(1.2-1.4 \mathrm{~g} \mathrm{~cm}^{-3}\right)$. Intra-bed boundaries clearly apparent in the core scan coincide with "steps" in magnetic susceptibility and density values (dashed lines in Fig. 3). The thicknesses of individual turbidites vary considerably. In the Quaternary sediments, i.e in the uppermost $123 \mathrm{~m}$, thicknesses range from 0.2 to $55.3 \mathrm{~cm}$, while they reach up to $95.3 \mathrm{~cm}$ in the Pliocene.

The internal structure of the individual turbidites suggests a similarity to the graded beds described by Bouma (1962) and by Talling et al. (2012), being deposited by a turbidity flows in the marine environment. Turbidites deposited in lacustrine environments are generally incomplete compared to the ideal "Bouma sequence" as the sedimentary structures (e.g., parallel or ripple-cross lamination) are often absent due to the short duration of the mass flow in a confined basin (Sturm and Matter, 1978). The thin basal sand unit of Lake El'gygytgyn turbidites shows faint planar lamination in thicker turbidites and can be correlated to the $\mathrm{T}_{\mathrm{B}-1}$ unit of Talling et al. (2012) that is deposited from a dilute flow. A ripple-cross-laminated $T_{C}$ unit is not found. The overlying coarse silt to silt unit correlates to $\mathrm{T}_{\mathrm{D}}$, though no planar lamination is observed. The capping silty clay to clay unit corresponds to their $\mathrm{T}_{\mathrm{E}}$. According to the classification of Talling et al. (2012) Lake El'gygytgyn turbidites are lowdensity turbidites.

\subsection{Grain-flow deposits (G)}

Massive, well-sorted grayish sand (Fig. 4) with sharp contacts to underlying sediment occur only once in the Quaternary and seven times in the Pliocene sediments drilled at ICDP Site 5011-1 (Fig. 2). The thicknesses of the deposits 


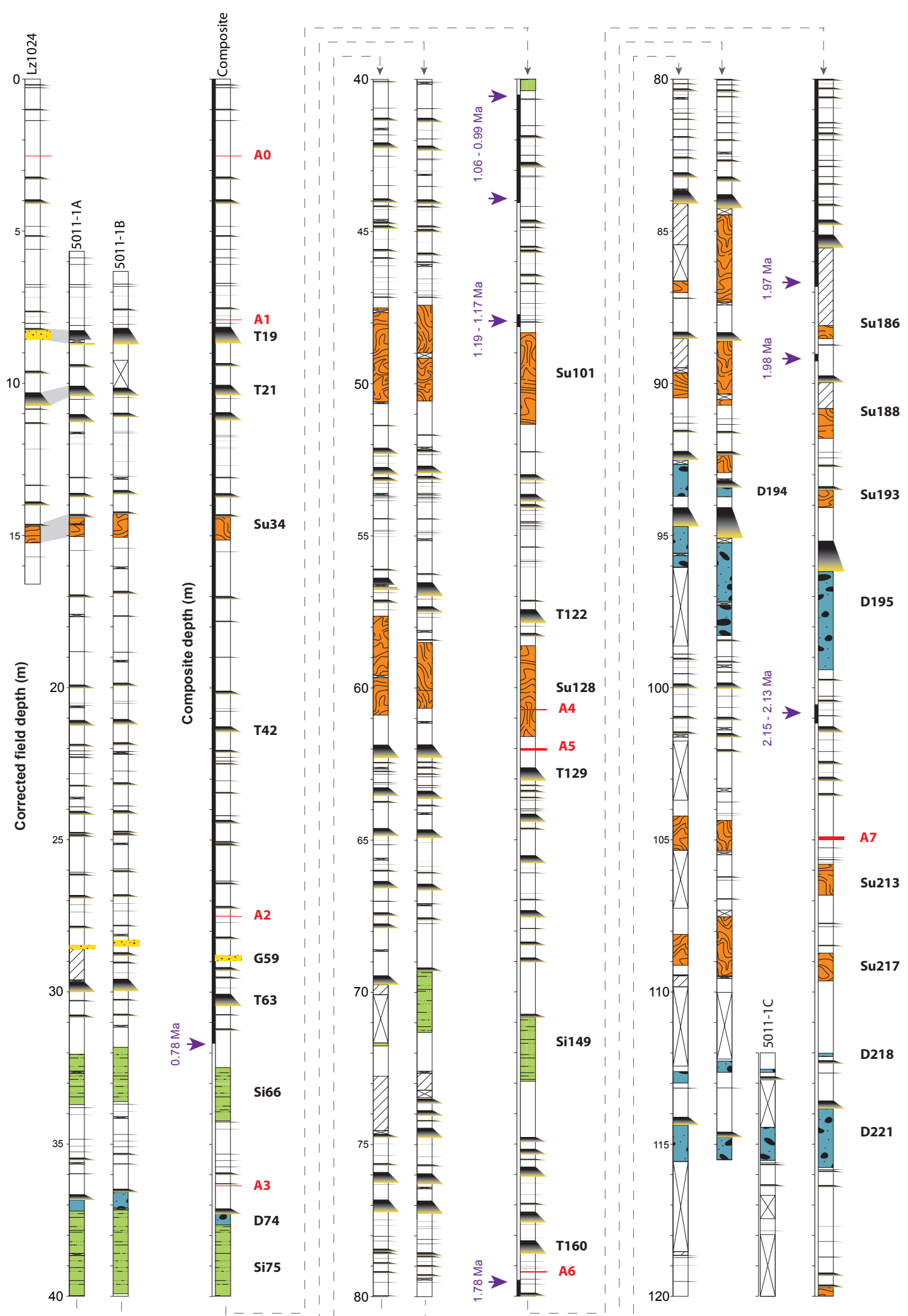

Fig. 2. Caption on next page. 


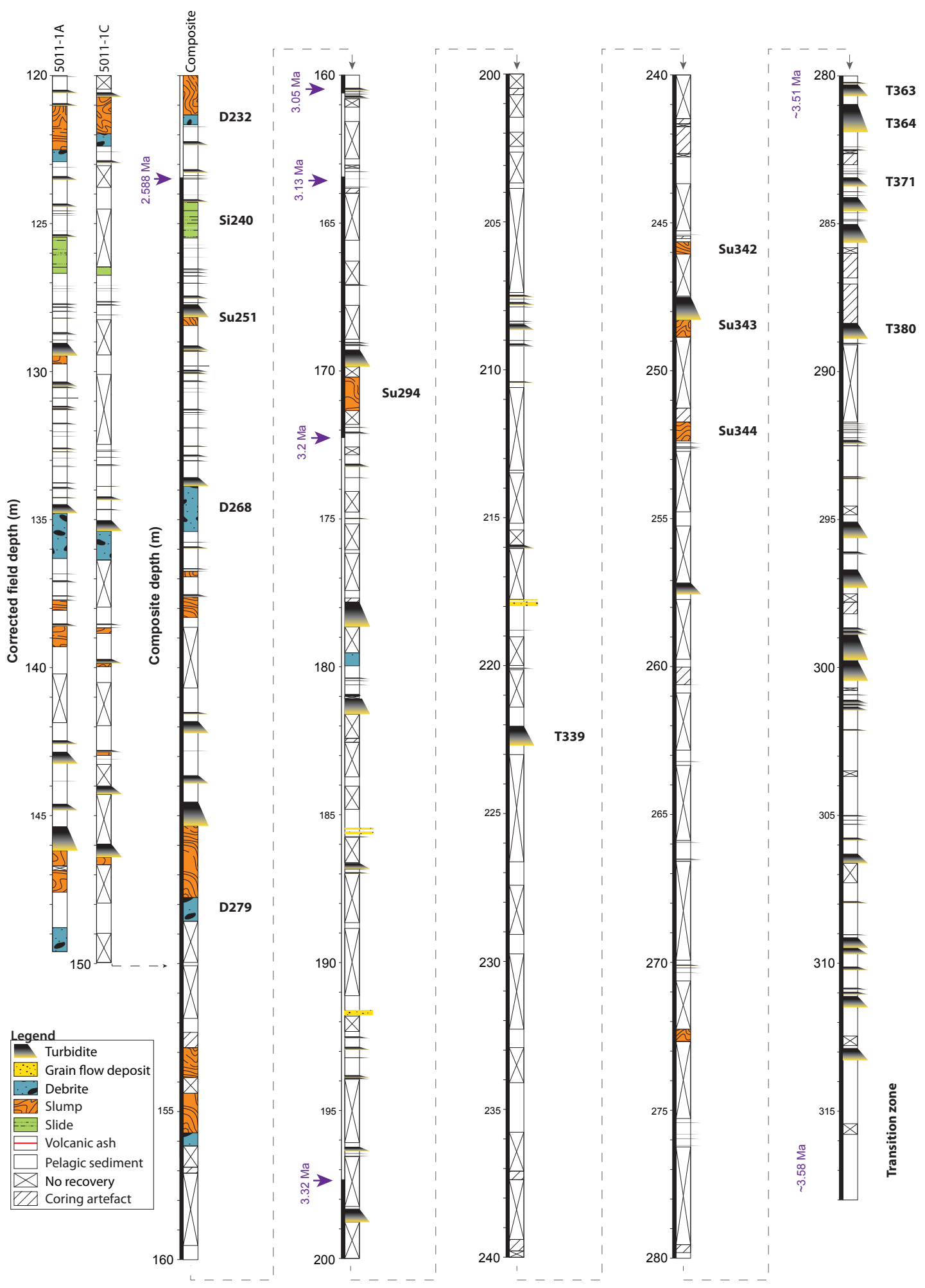

Fig. 2. Distribution of MMDs during the past 3.6 Ma from parallel cores at Lake El'gygytgyn (note: Lz1024 against composite depth and 5011-1A to 1C against corrected field depth). Composite of the mass movement events is against composite depth, which explains the small differences compared to the corrected field depth. Numbered mass movement events are mentioned in the text. Paleomagnetic polarity is indicated by black (normal) or white (reversed) rectangles, and ages of reversals (Haltia and Nowaczyk, 2013; Nowaczyk et al., 2013) are marked. 


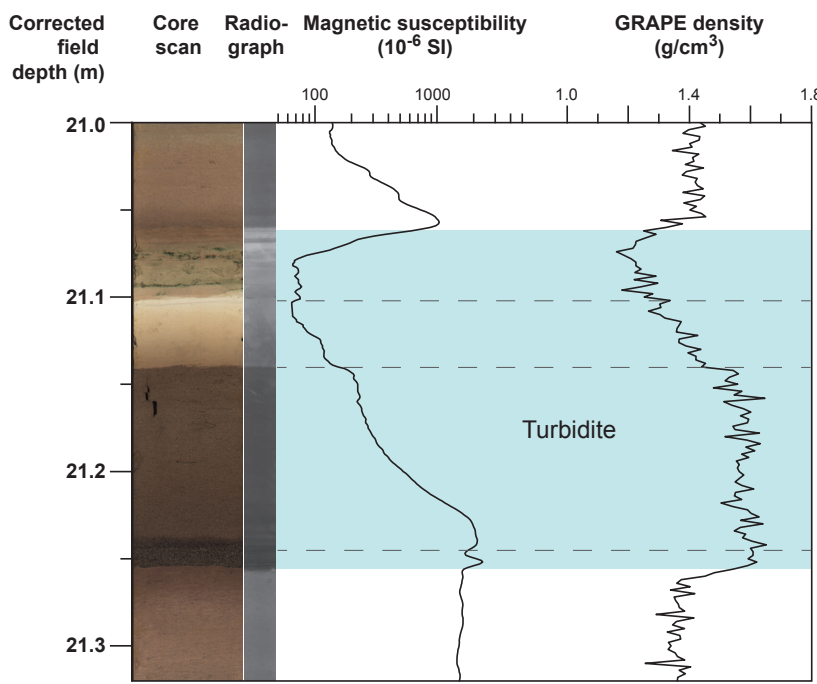

Fig. 3. Turbidite T42 (age $482 \mathrm{ka}$ ) in a core scan from 5011-1A$6 \mathrm{H}-1$ resembles a "Bouma sequence" (Bouma, 1962). The different subunits of the turbidite are readily identifiable from the reddish pelagic sediment based on color. The upper boundary of T42 is obscured by a greenish redox layer, but compositional grading is revealed by radiograph, magnetic susceptibility and density. Both magnetic susceptibility and density are high at the base of the turbidite and decrease towards the clayey top. Intra-bed boundaries (dashed line) between subunits are marked by "steps" in magnetic susceptibility and density values.

vary between 3.3 and $26.2 \mathrm{~cm}$. They lack any sedimentary structures and radiographs confirm a homogenous appearance without grading. Magnetic susceptibility values are only slightly higher compared to the adjacent pelagic sediments, whereas density is significantly increased.

The sand layers are interpreted as grain-flow deposits (Mulder and Alexander, 2001). These MMDs are products of mass flows, whose sediment concentration and grain size is too high to support turbulent flow; that is, they are laminar flows (Mulder and Alexander, 2001; Gani, 2004). Grain flows originate from areas where well-sorted sand is present to provide the requisite source material. In Lake El'gygytgyn, this probably is the case in deltas, which today occur in larger size predominantly at the western lake shore (Schwamborn et al., 2012).

\subsection{Debrites (D)}

These deposits are characterized by poorly sorted fine gravel and sand in a dark gray (Munsell color 5Y 4/1 to N4) silty to clayey matrix (Fig. 5). The subangular gravel grains present various lithologies available in the catchment. The contact to the underlying sediment is sharp. Thicknesses vary between 21.1 and $399.4 \mathrm{~cm}$. These deposits may have clasts of redeposited pelagic sediment in their upper parts, and may include gray or greenish lenses of folded or bent fine sediment (e.g., at $114.6 \mathrm{~m}$ cfd in Fig. 5). Additionally, they are nearly

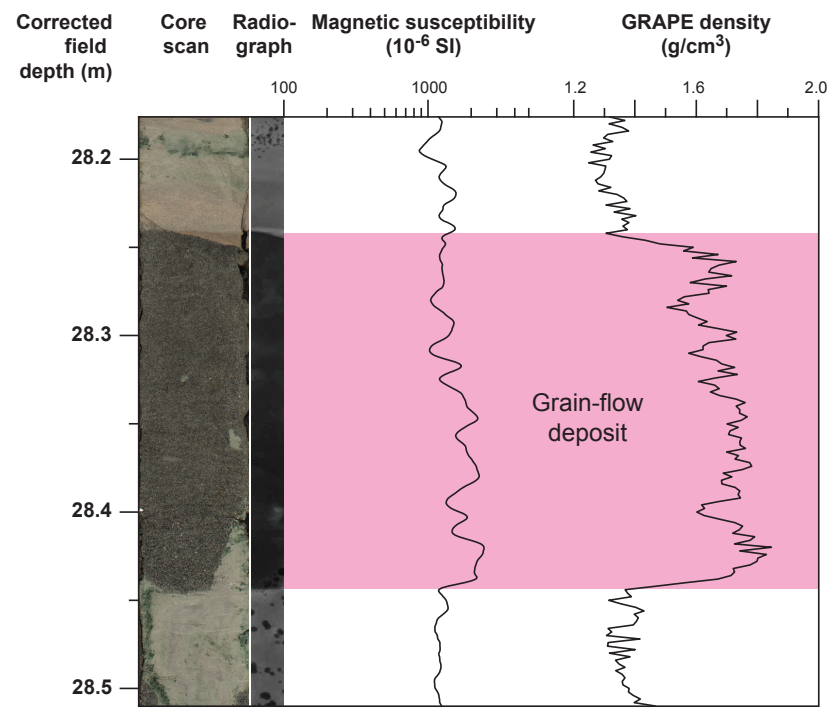

Fig. 4. Grain-flow deposit G59 (age $666 \mathrm{ka}$ ) in a core scan from 5011-1B-8H-1. Radiograph confirms the massive nature of the deposit. Magnetic susceptibility is somewhat higher, while density is clearly higher within the grain-flow deposit compared to pelagic sediments.

always overlain by a turbidite (Fig. 2). Magnetic susceptibility values are high, but similar to pelagic sediments of facies B. In contrast, density values with 1.7 up to $2.2 \mathrm{~g} \mathrm{~cm}^{-3}$ are generally higher compared to other MMDs as well as pelagic sediments at similar depths. In radiographs, these deposits appear dense and massive.

This type of deposit occurs 10 times in the sediment record, the uppermost (D74) at $37 \mathrm{~m} \mathrm{cfd}$ and all others below $92 \mathrm{~m}$ cfd. The characteristics of these deposits indicate complete mixing of the source material, i.e., formation by cohesive debris flows resulting in a debrite (Mulder and Alexander, 2001; Gani, 2004). A cohesive debris flow is indicated by the poor sorting, with a grain-size spectrum ranging from fine gravel to clay, and the lack of grading. Redeposited pelagic sediment clasts are transported by the debris flows and concentrated in the upper part of the deposit (Mulder and Alexander, 2001). The seismic survey at Lake El'gygytgyn (Niessen et al., 2007) yielded several debris flows on the lake slopes, especially in the west, but also in the north. The capping turbidite is interpreted as debris-flow generated.

\subsection{Slumps $(\mathrm{Su})$}

Altogether 17 sediment horizons have been identified in Lake El'gygytgyn record, in which the deposits are either folded, bent or the original structures are deformed (Fig. 6). Nevertheless, the facies of the source sediment is still widely identifiable, indicating that deformation and transport have been limited. The deposits are comprised of redeposited pelagic facies as well as event layers, such as volcanic ashes or turbidites, and can have basal or intercalated massive sand 


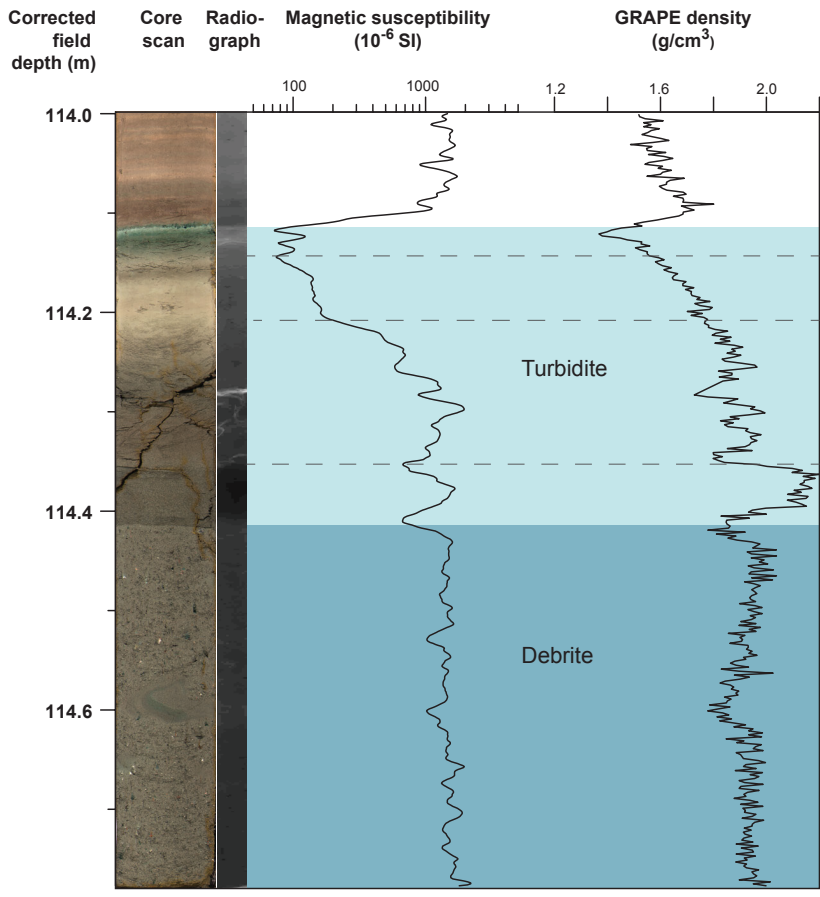

Fig. 5. A section of debrite D221 (age 2.43 Ma) in a core scan from 5011-1A-38H-3. It consists of a basal debrite and a directly overlying debris-flow-induced turbidite. Both magnetic susceptibility and density are high throughout the debrite. Density increases in the basal sand of the turbidite, while generally density values are the same or lower. Variation of magnetic susceptibility and density within the sandy and silty parts of the turbidite (114.25$114.38 \mathrm{~m} \mathrm{cfd}$ ) are caused by cracks in the core. Both parameters decrease towards the clayey top. Intra-bed boundaries (dashed line) between subunits of the turbidite are marked by "steps" in magnetic susceptibility and density values.

layers. Where a basal sandy unit is absent, the lower boundaries of these deposits are indistinct. Both magnetic susceptibility and density values vary according to the facies of the source material. These MMDs range in thickness between 37.0 and $337.2 \mathrm{~cm}$. They are interpreted as slumps, where external stress leads to deformation and minor redistribution of cohesive sediments.

The identification of Su34 in the drill cores leads to a new interpretation of the comparable section in the pilot core Lz1024 (Fig. 2). Su34 is 63.2 and $75.9 \mathrm{~cm}$ thick in cores 5011-1A and 5011-1B, respectively. It consists of a basal massive sandy layer (thickness in 1A and 1B 4.4 and $8.2 \mathrm{~cm}$, respectively), followed by folded pelagic sediment with an incised massive sandy layer. The folded sediment is directly overlain by a turbidite. The sand layers correlate with two layers at 1501.6 and $1508.8 \mathrm{~cm}(\mathrm{~cd})$ in the pilot core Lz1024 that were interpreted as grain-flow deposits by Juschus et al. (2009). Taking the wider picture now available from three parallel cores, these sediments are reinterpreted to belong to the larger and more complex slump Su34, in which pelagic

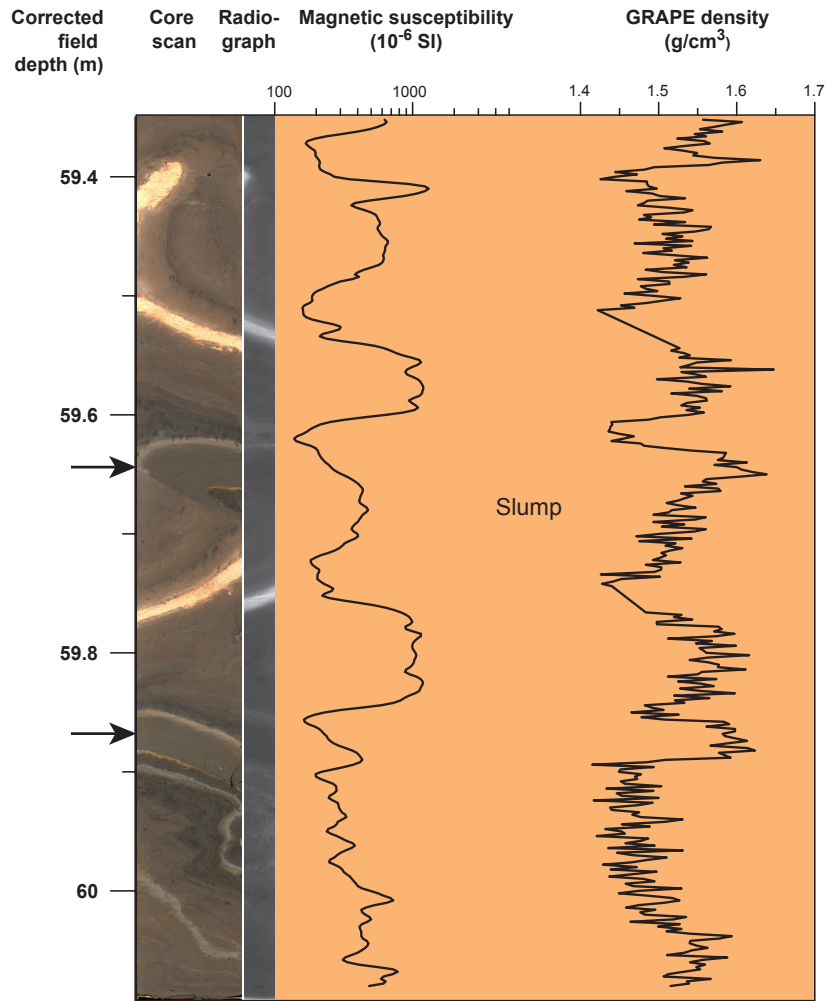

Fig. 6. A $75 \mathrm{~cm}$ thick section of slump Su128 (age 1.41 Ma) in a core scan from 5011-1B-18H-2. This section includes a folded tephra layer (orange in core scan) and a bent turbidite occurring twice (arrows). The sediments right above and below the duplicated turbidite (thickness $<3 \mathrm{~cm}$ ) belong to facies $\mathrm{A}$, whereas the remaining sediments belong to facies B. Both magnetic susceptibility and density vary according to the pelagic facies or event layer. Some unusually low density values in the tephra layers were deleted, resulting in gaps in the data.

facies of different types (facies A in core Lz1024, and facies $\mathrm{B}$ in cores 5011-1A and 1B) were incised.

\subsection{Slides (Si)}

In these deposits specific sediment features occur multiple times. The respective horizons lack visible folding and are comprised of various redeposited pelagic sediment facies, which are still widely undisturbed. In most cases, the multiplicated segments range from centimeters to tens of centimeters, while a $1.4 \mathrm{~m}$ thick duplicated segment comprises Si75 (Fig. 7) and was recovered in both holes 1A and 1B (Fig. 2). The segment includes a basal massive silty sand unit overlain by a small pelagic lens and a turbidite (between 40.0 and $39.7 \mathrm{~m}$ cfd; thickness $33 \mathrm{~cm}$ ), which in turn is overlain by pelagic sediments between 39.7 and $38.65 \mathrm{~m}$ cfd (thickness $107 \mathrm{~cm}$ ). Above the intra-slide boundary this segment is duplicated. The pelagic sediment appears widely undisturbed, and only the duplication of this specific sediment succession, reflected also by magnetic susceptibility and density 


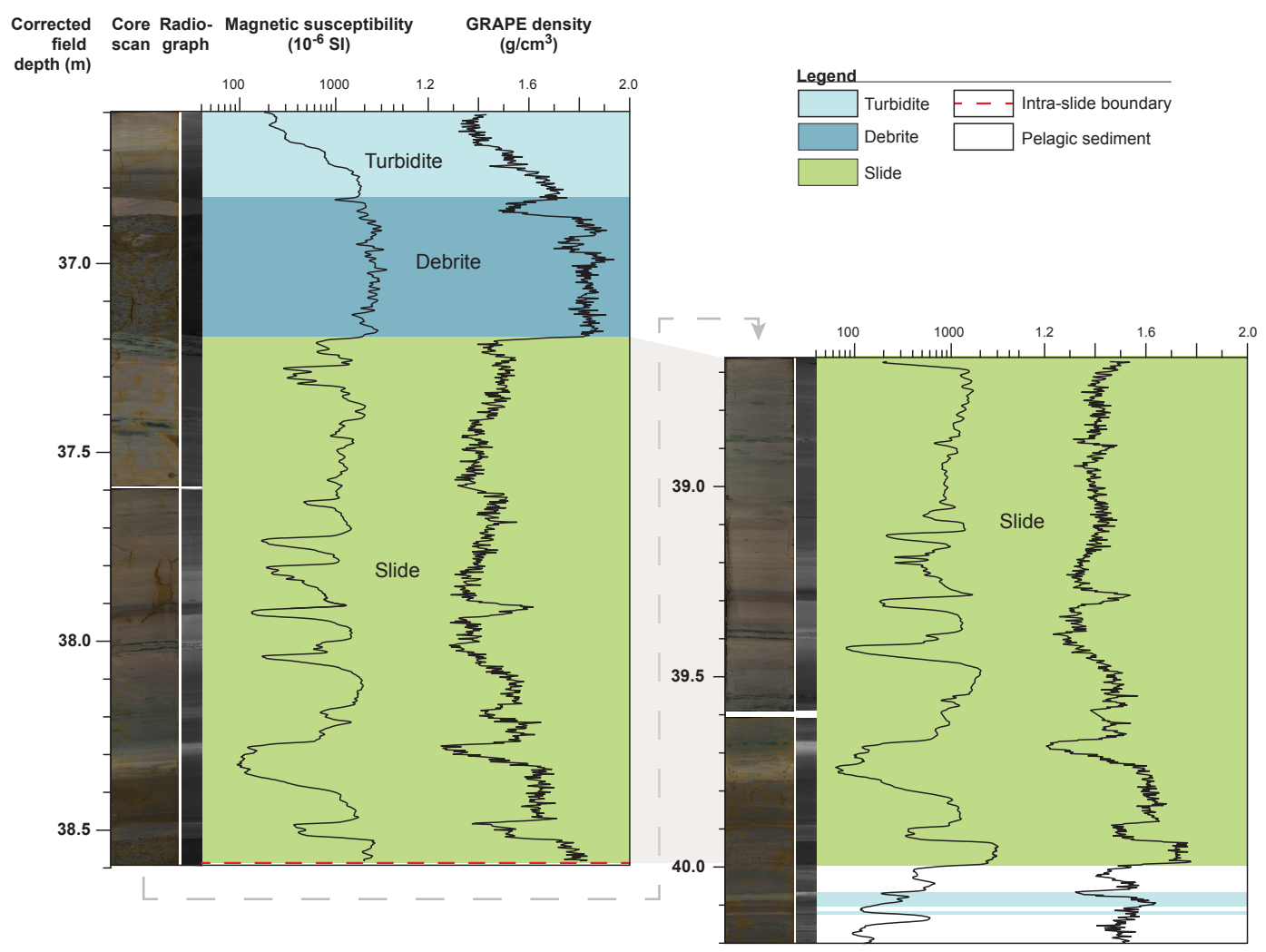

Fig. 7. Slide Si75 (age $930 \mathrm{ka}$ ) and overlying debrite D74 in core scans 5011-1A-11H-2 to 1A-12H-2. Slide Si75 consists of a ca. $140 \mathrm{~cm}$ thick duplicated section above and below the intra-slide boundary. The section is divided into a basal co-generic debrite-turbidite (39.7$40.0 \mathrm{~m}$ cfd; thickness $33 \mathrm{~cm}$ ) overlain by a $1 \mathrm{~m}$ segment of facies B sediments (38.65-39.7 m cfd). Both magnetic susceptibility and density of facies B sediments correlate nearly perfectly above and below the intra-slide boundary.

measurements, confirms that mass movement took place. The duplicated section is directly overlain by a debrite and co-generic turbidite (D74) at 36.6-37.2 m cfd (Fig. 2). As with slump deposits, the magnetic susceptibility values vary according to the source sediment. Thicknesses of this MMD type at site 5011-1 range from 23.4 to $272.3 \mathrm{~cm}$. Thin massive sand occasionally intercalates in the deposit. The absence of a parallel core hinders the identification of this deposit type below $150 \mathrm{~m} \mathrm{~cd}$, and might thus have led to overlooking of some of this deposit.

Sediment sliding is interpreted as the cause of multiplication of specific sediment sections. It may be related to debris flows since one debrite (D74) directly overlies this deposit (Si75; Fig. 2). Sliding would take place on a weak sediment layer and lead to disintegration of sediment packages. According to Schnellmann et al. (2005), sediments with comparable characteristics were traced back to external stress on cohesive sediments, leading to duplication of sediment units over relatively short distances along thrust faults. Another possible explanation for this deposit might be the retrogradation of an initial slope failure resulting in instability in adjacent areas (Mulder and Cochonat, 1996). However, as this would happen on the lake slope, which is several kilometers away from the coring site, it is unlikely that the sediments would reach the site as undeformed as they are. Additionally, the characteristics of pelagic sediments on the lake slope vary from those in the center, for instance by being somewhat coarser.

\section{Development of mass movement events}

Lake El'gygytgyn is prone to mass movement processes since it possesses a narrow shelf and a sharp shelf break at a depth of ca. $12 \mathrm{~m}$ in a bowl-shaped basin. Although sedimentation rates have generally been low back to about 3.3 Ma, sedimentation has been continuous during the entire lake's past ensuring adequate sediment delivery into the basin. Based on the observations made on the drill cores from ICDP Site 5011-1, a simplified model of the mass movement processes in Lake El'gygytgyn was developed (Fig. 8).

\subsection{Model of mass movement processes}

We suppose that the formation of MMDs in Lake El'gygytgyn is associated with an initial sediment failure on the upper lake slope that advances towards the lake basin. 


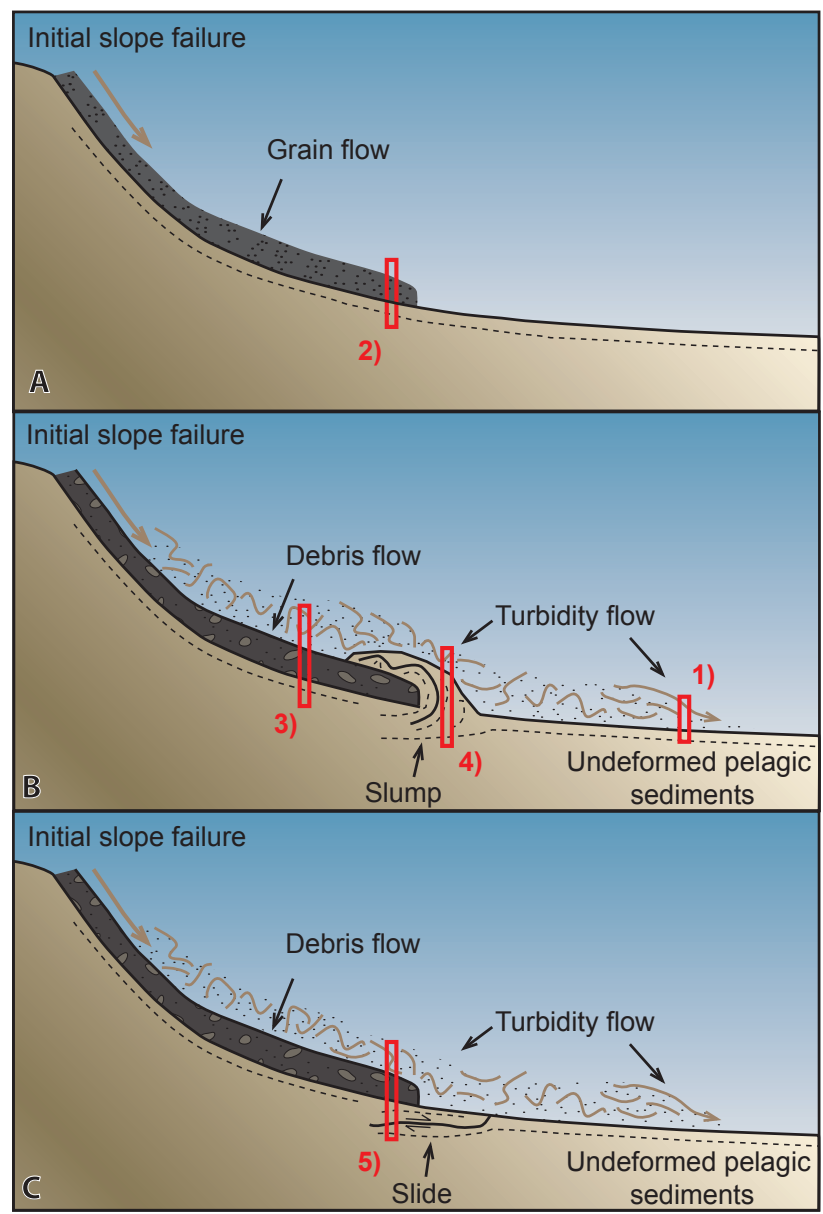

Fig. 8. Illustration of the evolution of mass movements in Lake El'gygytgyn. (A) Delta collapses of well-sorted material result in grain flows where the sediment density and grain size is too high to support turbulence. (B) Debris flow deforms pelagic sediments and creates co-generic turbidity current in front and on top of the debris flow. (C) Slide deposits encountered at the lake center may be caused by debris flows. Red rectangles indicate examples of the mass movement types (1) turbidite (Fig. 3), (2) grain-flow deposit (Fig. 4), (3) co-generic debrite-turbidite (Fig. 5), (4) slump (Fig. 6) and (5) slide-debrite (Fig. 7).

In the case of well-sorted sand as source material, which is the case for deltaic deposits at the western lake shore, the mass movement takes place as a laminar grain flow. This is not associated with significant turbulent flow, since the flow lacks fine-grained sediment components (Fig. 8a). Generally, sharp contacts to the underlying pelagic sediments suggest that grain-flow events are associated with erosion of previously deposited sediments along their flow paths.

In the case of coarse-grained, poorly sorted sediment as source material, slope failures lead to the formation of debris flows (Fig. 8b and c). Debrites are the coarsest sediments recovered in the center of Lake El'gygytgyn. Their origin from shallow water depths, outside the deltas with well-sorted sand at the western lake shore, is supported by the recovery of grayish sand and gravel in a short sediment core from $12 \mathrm{~m}$ water depth at the southern shelf (Juschus et al., 2011).

During their advance, debris flows become partly diluted and sediment is brought into suspension. The lower density of the suspension leads to a turbid flow above the debris flow that is finally deposited in the lake basin as a normally graded turbidite, both on top and in front of the debris flow. Turbidites generated by and directly overlaying debris flows are common in lacustrine and marine settings (e.g., Schnellmann et al., 2005; Waldmann et al., 2010; Rothwell et al., 2000; Strachan, 2008). However, since the debris flows in most cases do not extend all the way to the lake center, the associated turbidites there are more widespread than other MMDs (Schnellmann et al., 2005; Juschus et al., 2009). While the formation of debrites in Lake El'gygytgyn has been shown to be associated with significant erosion of previously deposited sediments, erosion by turbidites is regarded as minor, despite the genesis from turbulent flow and frequently occurring sharp lower boundaries (Juschus et al., 2009). This may be explained by the considerable amount of thin turbidites identified in the 5011-1 cores, denoted by the median thickness $(2.9 \mathrm{~cm}$ in the Quaternary and $2.3 \mathrm{~cm}$ in the Pliocene). The generally thin nature of turbidites suggests that most of them could be located distally, as turbidites have been observed to grade distally from the source area, resulting in finer and thinner distal turbidites (Sturm and Matter, 1978; Monecke et al., 2004; Girardclos et al., 2007). Therefore, the high number of thin turbidites at the drill site of Lake El'gygytgyn, located slightly to the east of the lake center, might indicate that they may have originated from the western lake slope, which is also supported by the seismic survey.

Furthermore, the debris flows may deform previously deposited sediments that become partially disintegrated, thus leading to the formation of slumps and slides (Fig. $8 \mathrm{~b}$ and c). Slumps are associated with limited deformation of the sediments, still showing original structures and facies. This suggests that the sediments incorporated in the slumps were not transported far away from the area where they were originally deposited. Since slumps are often directly overlain by turbidites, and found overlying debrites, at least twice in the record (D232 at 119.6-121.6 m, D279 at 144.5-148.6 m; Fig. 2), their formation is likely linked to debris flows. For most of the slumps, however, there is no indication of debris flows reaching the coring site. Hence, the folding and bending of sediment is assumed to have resulted from deformation by a debris flow, but primarily in its front and only occasionally at its base.

Rarely, debris flows can also lead to sediment sliding in the lake center, leading to the multiplication of specific sediment sections (Fig. 8c). This is suggested by a debrite (D74) found directly above a slide deposit (Si75; Fig. 7). It is presumed that slides can form in Lake El'gygytgyn, when debris flows build up stress on sediment that is more rigid and 
becomes locally displaced in the form of thrust faults, without folding, homogenization or water uptake. Another possible explanation for the slides might be the retrogradation of an initial slope failure resulting in instability in adjacent areas (Mulder and Cochonat, 1996). However, as this process would happen on the lake slope, which is several kilometers away form the coring site, it is unlikely that the sediments would reach the site as undeformed as they are. Furthermore, faults likely associated with the central uplift structure of the impact crater were found in the seismic profiles (Niessen et al., 2007). These faults are currently inactive, but were certainly active during the Pliocene and also during parts of the Pleistocene. Such faults were found west of the drilling location and may also be related to the formation of slumps and slides.

\subsection{Possible triggering mechanisms for mass movement events}

Several processes can trigger mass movements, including earthquakes, considerable lake-level changes, sediment overloading, delta collapses and extreme flooding events. Evidence of synchronous events within a lake basin points at a regional triggering mechanism such as seismic shaking or lake-level changes rather than local sediment failures due to overloading on the lake slope (e.g., Locat et al. 2003). At Lake El'gygytgyn extreme flooding events as the cause of MMDs can be considered minimal, as the precipitation and water discharge from the inlet creeks is small (Fedorov et al., 2013). Though precipitation has been considerably higher during peak warm interglacials and also during the Pliocene (Melles et al., 2012; Brigham-Grette et al., 2013), it probably was not enough to cause extreme flooding. Additionally, the internal structure of the majority of the turbidites does not suggest formation by hyperpycnal flows, where the deposit would have a basal coarsening upward unit overlain by a fining upward unit (Mulder et al., 2003).

In the deep lake basin, the accumulated sediments are fine grained (Francke et al., 2013; Wennrich et al., 2013a), suggesting that the coarser grained mass movements, in particular debrites, but also grain flows and turbidites, originate from shallow water depths, where such sediments are found (Juschus et al., 2011). The large alluvial fan and its subaqueous prologation in the western and northern lake catchment provide coarser grained sediments into the lake basin (Schwamborn et al., 2012; Fedorov et al., 2013) and delta collapses account for some of the mass movements encountered at the lake center. This can also be seen as multiple mass flows on the western lake slope in the seismic profile (Fig. 1c).

The lake level is known to have fluctuated in the past and at least four former lake terraces are known with heights of 3540, 9-11, 3-5 and $-10 \mathrm{~m}$ (Glushkova and Smirnov, 2005b, 2007; Juschus et al 2011). In general, higher lake levels are thought to correlate to warmer climate periods, and lower terraces to colder stages (Juschus et al., 2011). Additionally, several pebble bars on the northern shore mark a gradual lake-level drop of $4 \mathrm{~m}$ during the Holocene (Schwamborn et al., 2008). In Lake Bosumtwi, deeper lake conditions are recorded as thick turbidite silt (Talbot and Delibrias, 1980; Shanahan et al., 2006). At Lake El'gygytgyn warm climate stages are characterized by slightly thicker turbidites as well as by the occurrence of other MMDs during these times, suggesting that there is a link between climate and mass movements. This link could be explained by the better availability of sediment during warm stages, when the active layer is thicker, supported by the availability of water as a transport agent when the precipitation is higher. This would lead to instability on the lake slope due to sediment overloading during longer periods of time.

A mercury survey of the soil air as well as analysis of modern sediments revealed elevated mercury values, indicating ongoing neotectonic activity in the vicinity of the lake (Fedorov and Kupolov, 2005; Wennrich et al., 2013a), supported by the faults within the sediment column revealed by the seismic survey (Niessen et al., 2007). Historical seismic data indicate two recent earthquakes (magnitude 4.4 in 1967 and 4.2 in 1999) that were probably not strong enough to mobilize sediment. Magnitudes of $>5$ are needed to mobilize sediment in other lakes or fjords (Monecke et al., 2004; St-Onge et al., 2012).

Since the coarser grained sediments in the marginal lake areas prevent penetration of acoustic energy, the seismic data available cannot be used to identify the source areas for the mass movements directly. In addition, mapping of debris flows in the seismic profiles is hampered in the proximal areas due to low penetration on the lake slope. However, the direction of their origin is indicated in the profiles as debris flows are seen either parallel or transverse to the profile and thinning towards distal areas. While most of the debris flows appear to be single events, they cover large areas of the lake and have multiple lobes. This suggests a more regional triggering mechanism, at least for such larger events.

Consequently, paleo-earthquakes, lake-level changes, delta collapses, and overloading of the slope sediment remain the most plausible triggering mechanisms for mass movements at Lake El'gygytgyn.

\section{History of mass movement events}

Mass movement deposits in each drill hole at Lake El'gygytgyn are illustrated in Fig. 2. The drill cores 5011$1 \mathrm{~A}$ to $1 \mathrm{C}$ are shown in corrected field depth (cfd), while the pilot core Lz1024 (Juschus et al., 2009) and the composite are shown in composite depths (cd). Mass movements are numbered by events, starting from the youngest. Each event can consist of more than one type of deposit when they are interpreted as co-generic. 
Table 1. A summary table of Quaternary MMDs in Lake El'gygytgyn $(T=$ turbidite, $G=$ grain-flow deposit, $D=$ debrite, Si=slide, $\mathrm{Su}=$ slump).

\begin{tabular}{lrrrrrr}
\hline $\begin{array}{l}\text { MMD } \\
\text { type }\end{array}$ & $\begin{array}{r}\text { No. of } \\
\text { events }\end{array}$ & $\begin{array}{r}\text { Mean } \\
\text { thickness } \\
(\mathrm{cm})\end{array}$ & $\begin{array}{r}\text { Median } \\
\text { thickness } \\
(\mathrm{cm})\end{array}$ & $\begin{array}{r}\text { Total } \\
\text { thickness } \\
(\mathrm{m})\end{array}$ & $\begin{array}{r}\% \text { of } \\
\text { tot. MMD } \\
\text { thickness }\end{array}$ & $\begin{array}{r}\% \text { of } \\
\text { composite } \\
\text { record }\end{array}$ \\
\hline $\mathrm{T}$ & 213 & 6.6 & 2.9 & 14.2 & $34.6 \%$ & $11.5 \%$ \\
$\mathrm{G}$ & 1 & 19.6 & 19.6 & 0.2 & $0.5 \%$ & $0.2 \%$ \\
$\mathrm{D}$ & 6 & 154.1 & 131.7 & 9.2 & $22.6 \%$ & $7.5 \%$ \\
$\mathrm{Si}$ & 3 & 216.2 & 216.2 & 6.5 & $15.9 \%$ & $5.2 \%$ \\
$\mathrm{Su}$ & 7 & 154.4 & 101.4 & 10.8 & $26.4 \%$ & $8.7 \%$ \\
\hline \multicolumn{7}{r}{} \\
\hline
\end{tabular}

\subsection{Quaternary}

Altogether 230 mass movement events are identified in the Quaternary composite record (upper $123.5 \mathrm{~m}$ ), comprising $33 \%$ of the total sediment thickness (Table 1, Fig. 2). Juschus et al. (2009) reported that the pilot cores Lz1024 and PG1351, which comprise the last ca. 350 and $250 \mathrm{ka}$ (Nowaczyk et al., 2007; Frank et al., 2013), had only 12.7 and $7.1 \%$ MMDs, respectively. The considerably higher portion of mass movements in the drill cores is explained by new types of deposits as well as by the increase in their thickness in deeper core sections. This reflects a significant decrease in mass movement contribution to the sedimentation in central Lake El'gygytgyn in the course of the Quaternary. The recurrence time for Quaternary turbidites is $12 \mathrm{ka}$.

The mass movement events (and their portion to the total sediment thickness) are divided into 213 turbidites (11.5\%), 1 grain flow (0.2\%), 6 debrites $(7.5 \%), 7$ slumps $(8.7 \%)$ and 3 slides (5.2\%) (Table 1). The mean and median thicknesses of single turbidites are only 6.6 and $2.9 \mathrm{~cm}$, respectively. Due to generally low thicknesses compared to other mass movements, turbidites account for $93 \%$ of the number of mass movement events, but only $\sim 35 \%$ of their thickness. Their portion of the thickness of the Quaternary sediments $(11.5 \%)$ correlates well to their percentage in core Lz1024 (10.2\%, Juschus et al., 2009), suggesting that the decrease in mass movement deposition in the course of the Quaternary is widely independent of turbidites but mainly controlled by other types of mass movements.

The majority of Quaternary turbidites $(73 \%)$ are intercalated in facies B (warm) sediment, which contributes $79 \%$ of the pelagic Quaternary record (Melles et al., 2012), while facies A (cold) and facies C (peak warm) hold only 23 and $3 \%$ of the turbidites, respectively. The remaining $1 \%$ are underlain by another, separate turbidite. The mean thickness of turbidites in facies A and B is 4.1 and $7.4 \mathrm{~cm}$, respectively. This reflects the difference between turbidites deposited in cold and warm climate conditions. Debrites, grain flows, slides and slumps were deposited exclusively during warm climate conditions (facies B), while slumps are intercalated also in facies $\mathrm{C}$ sediments. During warm climate stages, normal pelagic sedimentation is coarser compared to cold climates due to variations in clastic sedimentation (Francke et al., 2013). Mainly coarse silt and very fine silt fractions appear to be climate dependant. This could also explain the occurrence of thicker turbidites and of other MMDs during these times. Warm climates promote erosion in the catchment, as the active layer is thicker, and transport into the lake basin is supposed to be increased.

\subsubsection{Holocene and late Pleistocene}

Holocene sediments with a thickness of $90 \mathrm{~cm}$ were recovered along the late Pleistocene sediments in the pilot cores Lz1024 and PG1351 only, the drill core 5011-1 starts with the early part of the Eemian (Fig. 2). During the Holocene two turbidites reached the lake center; other mass movements did not occur (Juschus et al., 2009). T1 has an age between 3200 and 5500 uncal. ${ }^{14} \mathrm{C}$ yr and T2 is located only $5 \mathrm{~cm}$ below, being ca. 1000 yr older (Juschus et al., 2009; Nowaczyk et al., 2013). Both the Holocene and the late Pleistocene are characterized by particularly thin turbidites (Fig. 2) that have a recurrence interval of $10.5 \mathrm{ka}$.

\subsubsection{Middle Pleistocene}

The most significant feature of the Middle Pleistocene mass movements is the dominance of turbidites (Figs. 2 and 9). The turbidite succession is interrupted by only two other events: slump Su34 and grain-flow deposit G59 (Fig. 2). Slump Su34 has an approximate age of early MIS 9, and its lower and upper contacts are to warm facies B, but facies A, correlating to MIS $9 \mathrm{~b}$, occurs just ca. $7 \mathrm{~cm}$ above. Grain-flow deposit G59 is also placed in facies B, representing MIS 17. Only a few relatively thick turbidites were deposited during the Middle Pleistocene: T19, T21 and T63. T19 (depth 8.1$8.7 \mathrm{~m} \mathrm{~cd}$; thickness $55.3 \mathrm{~cm}$ ) was formed during late MIS 6 and is one of the few thick turbidites deposited in cold climate conditions (facies A). T21 $(10.0-10.4 \mathrm{mcd} ; 34.9 \mathrm{~cm})$ reached the lake center during the preceding MIS 7, and T63 


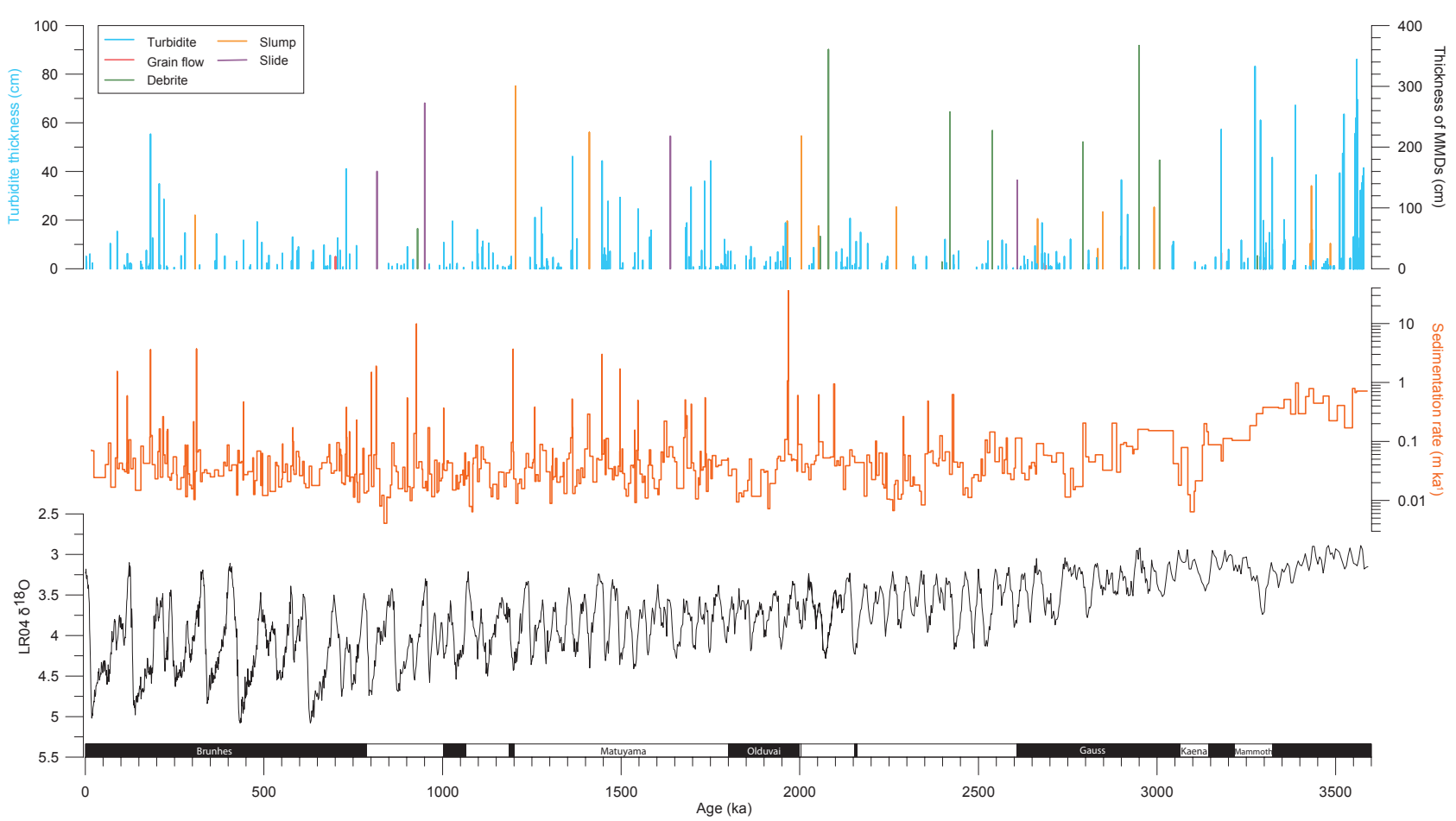

Fig. 9. Thickness of various MMDs compared with sedimentation rate and the LR04 global marine isotope stack (Lisiecki and Raymo, 2005).

(30.1-30.5 m cd; $41 \mathrm{~cm})$ is found in warm facies B sediments representing the warmest phase of MIS 18.

\subsubsection{Early Pleistocene}

Mass movement deposition during the early Pleistocene is characterized by the most frequent occurrence of debrites, slumps and slides during the entire lake's history (Fig. 9). During the first half of the early Pleistocene $(85-123.5 \mathrm{~m} \mathrm{~cd}$, corresponding to $1.96-2.6 \mathrm{Ma}$ ) normal pelagic and turbidite deposition is interrupted by several slumps and debrites (Figs. 2 and 9). The second half of the early Pleistocene $(31.7-85 \mathrm{~m} \mathrm{~cd}, 0.78-1.96 \mathrm{Ma})$, in contrast, is characterized by mass movement events that intercalate normal pelagic and turbidite deposition at more regular intervals. The events Si75 (early MIS 25), Su101 (MIS 35), Su128 (early MIS 45), and Si149 (MIS 56) occur at ca. 220 ka intervals. After Si75, it took ca. $130 \mathrm{ka}$ before Si66 was deposited, while before Si149 exclusively turbidites were deposited for ca. $290 \mathrm{ka}$ (73.0-85.0 m cd). Three slides (Si66, Si75 an Si149) occurred during the early Pleistocene. The youngest slide, Si66 at $32.5-34.2 \mathrm{mcd}$, overlies facies B sediments and was deposited during late MIS 21, while Si75 between 37.8 and $40.6 \mathrm{~m} \mathrm{~cd}$ (Si75) (Figs. 2 and 7) was deposited during early MIS 25. Two thick turbidites occur at depths of 57.4-57.9 $\mathrm{mcd}(\mathrm{T} 122 ; 46.1 \mathrm{~cm})$ and 62.6-63.1 $\mathrm{m} \mathrm{cd}$ (T129; $44.3 \mathrm{~cm}$ ), corresponding to MIS 43 and MIS 47, respectively.

The mass movement history during the first half of the early Pleistocene is characterized by several debrites and slumps between ca. 85 and $123.5 \mathrm{~m} \mathrm{~cd}$, while at the end of the first half between MIS 59 and 73, turbidite deposition dominated (Fig. 9). Especially at the end of this period thicker turbidites occurred, e.g., T160 (78.1-78.6 m cd; $44.3 \mathrm{~cm})$ during MIS 61. The lake center was reached by thick MMDs especially during the MIS 75-77 periods (Su186, Su188, Su193, D194) and the second half of MIS 79, when the thickest mass movement event, D195 (95.2-99.2 m cd), happened. This event consists of a $296.8 \mathrm{~cm}$ thick debrite overlain by a $102.6 \mathrm{~cm}$ thick turbidite, which is the thickest turbidite associated with a debrite in the whole Lake El'gygytgyn record. The event has an age of ca. 2.09 Ma, placing it to late MIS 79 (Nowaczyk et al., 2013). A lower lake level during MIS 80, indicated by the existence of green algae colonies, precedes this event (Andreev et al., 2013) but cannot be directly linked to these mass movement events. Additionally, during the MIS 87-93 periods several mass movement events entered the lake center (Su213, Su217, D218), coinciding with at least two peak warm interglacials of facies C (MIS 87 and 91). Event D221 occurred during MIS 95. D232 was deposited during late MIS 101. The Quaternary-Pliocene transition is marked by the first appearance of facies A sediments (Melles et al., 2012), which overlie Si240, indicating that this slide was deposited during significantly colder climate. Since there are small gaps in recovery in the lowermost $15 \mathrm{~m}$ of the early Pleistocene sediment record, corresponding to a time span of ca. $150 \mathrm{ka}$, some upper or lower contacts, and thus 
true thicknesses of these MMDs Su213, Su217 and D221 may be underestimated.

Although the debrites, slumps and slides during the first half of the early Pleistocene are deposited during warm to exceptionally warm climate phases, they do also coincide with the gradual increase in frequency and duration of cold climate stages between 2.3 and 1.8 Ma (Melles et al., 2012). After 1.8 Ma glacial-interglacial cyclicity was fully developed at Lake El'gygytgyn and can be correlated to the onset of the more regular intervals for mass movement events in the second half of the early Pleistocene.

\subsection{Pliocene}

In contrast to most of the Quaternary, the sediments deposited in central Lake El'gygytgyn during the Pliocene were not fully recovered. The findings provide a rough picture of the differences in mass movement activities between the Quaternary and the Pliocene. The recovery was nearly perfect between 123.5 and $149 \mathrm{mcd}$, as well as between 280 and $320 \mathrm{~m} \mathrm{~cd}$. Altogether 181 MMDs, contributing $32.5 \%$ to the recovered sediment thickness, have been identified: 161 turbidites (17.8\% of total recovered sediment thickness), 7 grain-flow deposits $(0.7 \%), 4$ debrites (7.3\%), 8 slumps $(5.5 \%)$ and 1 slide (1.3\%) (Table 2; Fig. 2). The Pliocene single turbidites have a mean and median thickness of 11.4 and $3.4 \mathrm{~cm}$, respectively, and they account for $90 \%$ of the amount of mass movement events. However, they comprise significantly more, $55 \%$, of the total thickness of mass movements in the Pliocene compared to the Quaternary. This reflects a considerable increase in turbidite thickness, as well as a decrease in the thickness of other MMD types in the Pliocene. The recurrence time for turbidites in the Pliocene until $3.51 \mathrm{Ma}$ is $8.9 \mathrm{ka}$, while in the lowermost $38 \mathrm{~m}$ of the core it shortens significantly to $1.2 \mathrm{ka}$.

Pliocene turbidites are partly intercalated in pelagic warm facies B (20.8\% of the thickness of turbidites). Additionally, they can overlie other single turbidites $(13 \%)$ or gaps in recovery $(19.7 \%)$. In the lowermost part of the record, turbidites incise facies $\mathrm{D}$, which is characterized by clayey to silty parallel laminations (11\%), and have a significantly higher average thickness of $9.63 \mathrm{~cm}$. Debrites, grain-flow deposits, and slides overlie mainly facies B sediments or core gaps.

If the poorer recovery within the Pliocene sediments were caused by higher amounts of coarser sediments, it would lead to an underestimation of MMDs in the Pliocene record. Concurrently, the recovered sediments would be biased towards the fine-grained pelagic sediments. Additionally, the lack of a parallel core through most of the Pliocene sediments, as well as the occasionally poorer quality of the recovered sediments, concentrated especially between ca. 223 and $245 \mathrm{~m} \mathrm{~cd}$, hampers the identification of some MMDs, particularly slides and slumps.

\subsubsection{Late Pliocene}

Late Pliocene sediments were recovered widely complete in holes $1 \mathrm{~A}$ and $1 \mathrm{C}$ down to $150 \mathrm{mcd}(2.94 \mathrm{Ma})$, below which information is only available from hole $1 \mathrm{C}$, including gaps in recovery up to $3.0 \mathrm{~m}$ in thickness. The upper part of the late Pliocene is characterized by several slides, slumps and debrites (Fig. 9) that occur at shorter intervals compared to the early Pleistocene. At the end of late Pliocene turbidites reached the coring site frequently. Nearly all identified MMDs are turbidites in the lower part of late Pliocene that includes several gaps in recovery (Fig. 2). Pelagic sediments of facies C overlie the debrite D268 at $133.6-135.6 \mathrm{mcd}$, suggesting that the event was deposited during a peak interglacial, possibly G9. Debrite D279 dominates the lowermost ca. $4 \mathrm{~m}$ of core 5011-1A and is the second thickest mass movement found in the 5011-1 cores (Fig. 2). Interestingly, both twist-offs in holes 1A (149 m cd) and 1B (115 m cd) occurred in debrites (D279 and D221, respectively). In hole $1 \mathrm{~A}$ the lower boundary of D221 was not recovered, nor was it in the upper boundary of hole $1 \mathrm{C}$, and in hole 1C D279 was not recovered at all. This suggests that both the twist-offs and the gaps in recovery can be related to coarser grained sediments associated with MMDs.

All of the Pliocene grain-flow deposits occur in the late Pliocene sediments between 185 and $218 \mathrm{~m}$ cd and lack a parallel core. As seen in Su34, these massive sandy deposits might belong to slumps. Thus, a parallel core would be crucial to confirm these deposits, especially given the fact that between 156.2 and $245.5 \mathrm{mcd}$ only one slump (Su294) and no slides are identified.

The Pliocene is characterized by higher sedimentation rates compared to the Quaternary (Fig. 9). At the end of the late Pliocene the sedimentation rate decreased to ca. $5 \mathrm{~cm} \mathrm{ka}^{-1}$, while below $160 \mathrm{~m}$ (3.05 Ma) sedimentation with $45 \mathrm{~cm} \mathrm{ka}^{-1}$ is almost 10 times higher (Nowaczyk et al., 2013).

\subsubsection{Middle Pliocene}

The transition from the late to the middle Pliocene is poorly documented due to the limited recovery and the poor quality of the recovered sediments from 223 to $245 \mathrm{~m} \mathrm{~cd}$. However, the recovered sediments are fine grained, excluding any major MMDs. Between 245 and $252.5 \mathrm{mcd}$ three slumps (Su342, Su343, Su344) were deposited during a fairly short time period of roughly $3.43-3.44 \mathrm{Ma}$. The recovery remains poor down to a depth of $280 \mathrm{~m} \mathrm{~cd}$ (ca. $3.51 \mathrm{Ma}$ ), below which it increases to almost $100 \%$ (Fig. 2). The lowermost $38 \mathrm{~m}$ correspond roughly to the first $70 \mathrm{ka}$ after the impact with a high sedimentation rate of ca. $50 \mathrm{~cm} \mathrm{ka}^{-1}$ (Nowaczyk et al., 2013). 
Table 2. A summary table of Pliocene MMDs in Lake El'gygytgyn $(\mathrm{T}=$ turbidite, $\mathrm{G}=$ grain-flow deposit, $\mathrm{D}=\mathrm{debrite}, \mathrm{Si}=\mathrm{slide}, \mathrm{Su}=\mathrm{slump})$.

\begin{tabular}{lrrrrrr}
\hline $\begin{array}{l}\text { MMD } \\
\text { type }\end{array}$ & $\begin{array}{r}\text { No. of } \\
\text { events }\end{array}$ & $\begin{array}{r}\text { Mean } \\
\text { thickness } \\
(\mathrm{cm})\end{array}$ & $\begin{array}{r}\text { Median } \\
\text { thickness } \\
(\mathrm{cm})\end{array}$ & $\begin{array}{r}\text { Total } \\
\text { thickness } \\
(\mathrm{m})\end{array}$ & $\begin{array}{r}\% \text { of } \\
\text { tot. MMD } \\
\text { thickness }\end{array}$ & $\begin{array}{r}\% \text { of } \\
\text { composite } \\
\text { record }\end{array}$ \\
\hline $\mathrm{T}$ & 161 & 11.4 & 3.4 & 18.3 & $54.7 \%$ & $17.8 \%$ \\
$\mathrm{G}$ & 7 & 10.5 & 8.3 & 0.7 & $2.2 \%$ & $0.7 \%$ \\
$\mathrm{D}$ & 4 & 187.5 & 180.7 & 7.5 & $22.4 \%$ & $7.3 \%$ \\
$\mathrm{Si}$ & 1 & 130.1 & 130.1 & 1.3 & $3.9 \%$ & $1.3 \%$ \\
$\mathrm{Su}$ & 8 & 70.7 & 67.9 & 5.7 & $16.9 \%$ & $5.5 \%$ \\
\hline \multicolumn{7}{r}{} \\
\hline
\end{tabular}

Several thick turbidites are deposited between $280 \mathrm{~m}$ and $300.5 \mathrm{~m} \mathrm{~cd}$, including the thickest single turbidite event in the entire record (T364; $95.3 \mathrm{~cm})$ at $281-282 \mathrm{~m} \mathrm{~cd}$. This turbidite has a $7.8 \mathrm{~cm}$ thick deformation zone (DZ) directly below, where the laminated pelagic sediments are disturbed. Similar deformation zones occur also beneath a few other turbidites, such as T339 $(59.6 \mathrm{~cm}, 222.0-222.7 \mathrm{~m} \mathrm{~cd})$, T363 $(39.3 \mathrm{~cm}$, $280.3-280.7 \mathrm{mcd}), \mathrm{T} 371(29.4 \mathrm{~cm}, 283.5-283.8 \mathrm{mcd})$ and T380 (51.1 cm, 288.4-288.9 m cd), but with 7.5, 2.0, 1.5 and $1.5 \mathrm{~m}$, respectively, they are significantly thinner. Erosion of the pelagic sediments is indicated, since within these deformation zones pelagic sediment is clearly cut or mixed with the basal sand of the turbidite.

Turbidites are the only MMDs found within the lowermost $38 \mathrm{~m}$ of the core. This could be explained by the higher relief of the impact crater and greater water depths shortly after the impact event $3.6 \mathrm{Ma}$ ago. The recurrence time of turbidites is only $1.2 \mathrm{ka}$. The content of sand in the sediment increases below $295 \mathrm{~m} \mathrm{~cd}$, indicating higher energies in the system. Sandy sediments alternate with clayey to silty sediments that are mostly laminated until a depth of $313.4 \mathrm{mcd}$. The lake was formed at the end of the early Pliocene, when tectonic uplift of Anadyr lowland was still ongoing, and it continued until the early Pleistocene (Glushkova and Smirnov, 2007). It is yet unknown how long it took for the lake to form. Nevertheless, the high relief, availability of loose material in a presumably sparsely vegetated environment and ongoing tectonic uplift probably promoted erosion during the early stages of the crater and lake filling, resulting in a much higher sedimentation rate and frequent mass movements. Below $314.4 \mathrm{~m}$ cd a breccia comprised of partly layered sand and a downwards-increasing percentage and diameter of lithic clasts reflects the transition zone between lake sediment and impact rocks. The clasts include shocked rocks and impact rocks to a depth of $318 \mathrm{mcd}$ (Raschke et al., 2013; Gebhardt et al., 2013). The transition zone likely represents the wash-out of sediments and rocks within the crater shortly after the impact.

\section{Conclusions}

Detailed sediment descriptions of the drill cores 5011-1A, $1 \mathrm{~B}$ and $1 \mathrm{C}$ from central Lake El'gygytgyn, along with measurements of magnetic susceptibility and gamma-ray density, have revealed the significance of mass movement events during the past 3.6 Ma. The following conclusions can be drawn concerning the genesis and history of mass movement events in the lake.

1. Mass movement deposits have frequently reached the coring site, which today is situated ca. $4 \mathrm{~km}$ away from the nearest shore. In the course of the lake's history at least 411 mass movement events have occurred. They contribute significantly to the sediment infill and account for $33 \%$ of the composite record thickness. The significance of MMDs increases downwards in the record.

2. Five different types of MMDs are identified, which have individual sedimentological characteristics: turbidites, grain-flow deposits, debrites, slumps and slides. These are deposited by transitional mass-flow processes and can thus be co-generic.

3. The nearly perfectly recovered $123 \mathrm{~m}$ long Quaternary record is characterized by $11.5 \%$ of turbidites and $21.6 \%$ of other MMDs. The mean rate of recurrence is $11.3 \mathrm{ka}$. During the past $800 \mathrm{ka}$, turbidites have dominated the mass-movement deposition at the coring site.

4. The $195 \mathrm{~m}$ long Pliocene record was drilled with only $52 \%$ recovery. The sediment recovered is characterized by $17.8 \%$ of turbidites and $14.7 \%$ other MMDs. During most of the Pliocene the mean rate of recurrence was $7.4 \mathrm{ka}$, while in the early lake stage it was only $1.2 \mathrm{ka}$.

5. Turbidites occur throughout the record and they are the most frequent MMD. They contribute $91 \%$ of the number of MMDs but only $44 \%$ of their thickness. Turbidites occur in all pelagic facies, but they are more abundant and thicker during warm climate conditions. 
6. Debrites, grain-flow deposits, slides and slumps have a higher potential for erosion than turbidites. They are less frequent, but due to their generally greater thickness compared to turbidites, they account for $56 \%$ of the MMD thickness. Debrites, grain-flow deposits, slides and slumps incise almost exclusively facies reflecting warm climate conditions.

Acknowledgements. We are grateful to the participants on the pilot expedition in 2003 and the drilling campaign in 2008/2009 at Lake El'gygytgyn for recovering the unique record and conducting initial core processing. Funding for the drilling campaign was provided by the International Continental Scientific Drilling Program (ICDP), the US National Science Foundation (NSF), the German Federal Ministry of Education and Research (BMBF), Alfred Wegener Institute (AWI) and GeoForschungsZentrum Potsdam (GFZ), the Russian Academy of Sciences Far East Branch (RAS FEB), the Russian Foundation for Basic Research (RFBR) and the Austrian Federal Ministry of Science and Research (BMWF). The Russian GLAD 800 drilling system was developed and operated by DOSECC, Inc., and LacCore, at the University of Minnesota, handled core curation. This study was financially supported by the German Research Foundation (DFG, grant ME 1169/21-1) and the German Federal Ministry for Education and Research (BMBF, grant no. 03G0642A). The authors would like to thank three anonymous reviewers for their constructive comments, which helped to improve the quality of the manuscript.

Edited by: J. Brigham-Grette

\section{References}

Andreev, A. A., Tarasov, P. E., Wennrich, V., Raschke, E., Herzschuh, U., Nowaczyk, N. R., Brigham-Grette, J., and Melles, M.: Late Pliocene and early Pleistocene environments of the north-eastern Russian Arctic inferred from the Lake El'gygytgyn pollen record, Clim. Past Discuss., 9, 4599-4653, doi:10.5194/cpd-9-4599-2013, 2013.

Belyi, V. F.: Structure and formation of the El'gygytgyn Basin (Anadyr Mountains), Geomorphologia, 1, 31-41, 2001.

Belyi, V. F. and Raikevich, M. I: The El'gygytgyn hollow - geology and morphology, impactites, problems of research and protection of an inanimate nature, NEISRI FEB Russian Acad. Sci., Magadan, 1994

Blass, A., Anselmetti, F., Grosjean, M., and Sturm, M.: The last 1300 years of environmental history recorded in the sediments of Lake Sils (Engadine, Switzerland), Eclogae Geol. Helv., 98, 319-332, doi:10.1007/s00015-005-1166-5, 2005.

Bøe, R., Longva, O., Lepland, A., Blikra, L. H., Søonstegaard, E., Haflidason, H., Bryn, P., and Lien, R.: Postglacial mass movements and their causes in fjords and lakes in western Norway, Norw. J. Geol., 84, 35-55, 2004.

Bouma, A. H.: Sedimentology of some Flysch deposits: a graphic approach to facies interpretarion, Elsevier, Amsterdam, 1962.

Brigham-Grette, J., Melles, M., and Juschus, O.: Terrace $10 \mathrm{~m}$ below lake level, The Expedition El'gygytgyn Lake 2003 Siberian Arctic, Rep. Polar Mar. Res., 509, 108-110, 2005.
Brigham-Grette, J., Melles, M., Minyuk, P., Andreev, A., Tarasov, P., DeConto, R., Koenig, S., Nowaczyk, N., Wennrich, V., Rosén, P., Haltia, E., Cook, T., Gebhardt, C., Meyer-Jacob, C., Snyder, J., and Herzschuh, U.: Pliocene warmth, extreme polar amplification, and stepped Pleistocene cooling recorded in NE Russia, Science, 340, 1421-1427, doi:10.1126/science.1233137, 2013.

Fedorov, G. and Kupolov, A.: Gas Mercury survey in the El'gygytgyn crater, in: The Expedition El'gygytgyn Lake 2003 Siberian Arctic, edited by: Melles, M., Minyuk, P., BrighamGrette, J., and Juschus, O., Rep. Polar Mar. Res., 509, 69-71, 2005.

Fedorov, G., Nolan, M., Brigham-Grette, J., Bolshiyanov, D., Schwamborn, G., and Juschus, O.: Preliminary estimation of Lake El'gygytgyn water balance and sediment income, Clim. Past, 9, 1455-1465, doi:10.5194/cp-9-1455-2013, 2013.

Feldman, V. I., Granovsky, L. B., Naumova, I. G., and Nikoshina, N. N.: Some peculiarities of the chemical composition of impactittes from the El'gygytgyn meteoric crater Chukotka, Meteoritics, 39, 110-113, 1980.

Francke, A., Wennrich, V., Sauerbrey, M., Juschus, O., Melles, M., and Brigham-Grette, J.: Multivariate statistic and time series analyses of grain-size data in Quaternary sediments of Lake El'gygytgyn, NE Russia, Clim. Past Discuss., 9, 217-244, doi:10.5194/cpd-9-217-2013, 2013.

Frank, U., Nowaczyk, N. R., Minyuk, P., Vogel, H., Rosén, P., and Melles, M.: A $350 \mathrm{kyr}$ record of climate change from Lake El'gygytgyn, Far East Russian Arctic: refining the pattern of climate modes by means of cluster analysis, Clim. Past Discuss., 8, 5109-5132, doi:10.5194/cpd-8-5109-2012, 2012.

Fujita, K., Koz'min, B. M., Mackey, K. G., Riegel, S. A., McLean, M. S., and Imaev, V. S.: Seismotectonics of the Chersky Seismic Belt, eastern Sakha Rebublic, (Yakutia) and Magadan District, Russia, Stephan Mueller Spec. Publ. Ser., 4, 117-145, 2009.

Gani, M. R.: From turbid to lucid: a straightforward approach to sediment gravity flows and their deposits, Sed. Rec., 2, 4-8, 2004.

Gebhardt, A. C., Niessen, F., and Kopsch, C.: Central Uplift Structure Identified in one of the World's Best Preserved Impact Craters, Geology, 34, 145-148, 2006.

Gebhardt, A. C., De Batist, M., Niessen, F., Anselmetti, F. S., Ariztegui, D., Haberzettl, T., Kopsch, C., Ohlendorf, C., and Zolitschka, B.: Deciphering lake and maar geometries from seismic refraction and reflection surveys in Laguna Potrok Aike (southern Patagonia, Argentina), J. Volcanol. Geoth. Res., 201, 357-363, 2011.

Gebhardt, A. C., Francke, A., Kück, J., Sauerbrey, M., Niessen, F., Wennrich, V., and Melles, M.: Petrophysical characterization of the lacustrine sediment succession drilled in Lake El'gygytgyn, Far East Russian Arctic, Clim. Past, 9, 1933-1947, doi:10.5194/cp-9-1933-2013, 2013.

Girardclos, S., Schmidt, O. T., Sturm, M., Ariztegui, D., Pugin, A., and Anselmetti, F.: The 1996 AD delta collapse and large turbidite in Lake Brienz, Mar. Geol., 241, 137-154, 2007.

Glushkova, O. Y. and Smirnov, V. N.: General geology and geography, in: The Expedition El'gygytgyn Lake 2003 Siberian Arcticedited, edited by: Melles, M., Minyuk, P., Brigham-Grette, J., and Juschus, O., Rep. Polar Mar. Res., 509, 14-18, 2005 a. 
Glushkova, O. Y. and Smirnov, V. N.: Coastal Morphology, in: The Expedition El'gygytgyn Lake 2003 Siberian Arctic, edited by: Melles, M., Minyuk, P., Brigham-Grette, J., and Juschus, O., Rep. Polar Mar. Res., 509, 104-108, 2005b.

Glushkova, O. Y. and Smirnov, V. N.: Pliocene to Holocene geomorphic evolution and paleo- geography of the El'gygytgyn Lake region, NE Russia, J. Paleolimnol., 37, 37-47, 2007.

Gurov, Y. P. and Gurova, Y. P.: El'gygytgyn meteoric crater on Chukotka as an example of young morphologically expressed crater, in: Geology and petrology of meteorite impact craters, edited by: Ryabenko, V. A., Science Thought Dumka, Kiev, 125135, 1981.

Gurov, Y. P. and Koeberl, C.: Shocked rocks and impact glasses from the El'gygytgyn impact structure, Russia, Meteorit. Planet. Sci., 39, 1495-1508, 2004.

Guyard, H., St-Onge, G., Chapron, E., Anselmetti, F. S., and Francus, P.: The AD 1881 Earthquake-triggered slump and Late Holocene flood-induced turbidites from proglacial Lake Bramant, western French Alps, in: Submarine Mass Movements and Their Consequences, edited by: Lykousis, V., Sakellariou, D., and Locat, J., Springer, 279-286, 2007.

Haltia, E. and Nowaczyk, N. R.: Paleomagnetic age constraints for the sediments from Lake El'gygytgyn (NE Siberia) during the last 3.6 Myr, Clim. Past Discuss., submitted, 2013.

International Seismological Centre: On-line Bulletin, http://www. isc.ac.uk, last access: 17 May 2013, Internatl. Seis. Cent., Thatcham, UK, 2011.

Juschus, O., Fedorov, G., Wennrich, V., and Quart, S.: Aeolian supply, in: The Expedition El'gygytgyn Lake 2003 Siberian Arctic, edited by: Melles, M., Minyuk, P., Brigham-Grette, J., and Juschus, O., Rep. Polar Mar. Res., 509, 52-54, 2005.

Juschus, O., Melles, M., Gebhardt, A. C., and Niessen, F.: Late Quaternary mass movement events in Lake El'gygytgyn, north-eastern Siberia, Sedimentology, 56, 2155-2174, doi:10.1111/j.1365-3091.2009.01074.x, 2009.

Juschus, O., Pavlov, M., Schwamborn, G., Preusser, F., Fedorov, G., and Melles, M.: Late Quaternary lake-level changes of Lake El'gygytgyn, NE Siberia, Quaternary Res., 76, 441-451, doi:10.1016/j.yqres.2011.06.010, 2011.

Kopsch, C.: Bathymetric measurements, in: The Expedition El'gygytgyn Lake 2003 Siberian Arctic, edited by: Melles, M., Minyuk, P., Brigham-Grette, J., and Juschus, O., Rep. Polar Mar. Res., 509, 129-131, 2005.

Layer, P. W.: ${ }^{40} \mathrm{Ar} /{ }^{39} \mathrm{Ar}$ age of the El'gygytgyn impact event, Chukotka, Russia, Meteorit. Planet. Sci., 35, 591-599, 2000.

Lisiecki, L. E. and Raymo, M. E.: A Pliocene-Pleistocene stack of 57 globally distributed benthic $\delta^{18} \mathrm{O}$ records, Paleooceanography, 20, PA1003, doi:10.1029/2004PA001071, 2005.

Locat, J., Martin, F., Levesque, A. J., Locat, P., Leroueil, S., Konrad, J. M., Urgeles, R., Canals, M., and Duchesne, M. J.: Submarine mass movements in the Upper Saguenay Fjord (Quebec Canada), triggered by the 1663 earthquake, in: Submarine Mass Movements and Their Consequences: 1st International Symposium, edited by: Locat, J., Mienert, J., and Boisvert, L., Kluwer, Dordrecht, 509-519, 2003.

Melles, M., Brigham-Grette, J., Glushkova, O. Y., Minyuk, P., Nowaczyk, N. R., and Hubberten, H.-W.: Sedimentary geochemistry of a pilot core from El'gygytgyn Lake - a sensitive record of climate variability in the East Siberian Arctic during the past three climate cycles, J. Paleolimnol., 37, 89-104, 2007.

Melles, M., Brigham-Grette, J., Minyuk, P., Koeberl, C., Andreev, A., Cook, T., Fedorov, G., Gebhardt, C., HaltiaHovi, E., Kukkonen, M., Nowaczyk, N., Schwamborn, G., Wennrich, V., and El'gygytgyn Scientific Party: The El'gygytgyn Scientific Drilling Project - conquering Arctic challenges through continental drilling, Scient. Drill., 11, 29-40, doi:10.2204/iodp.sd.11.03.2011, 2011.

Melles, M., Brigham-Grette, J., Minyuk, P. S., Nowaczyk, N. R., Wennrich, V., DeConto, R. M., Anderson, P. A., Andreev, A. A., Coletti, A., Cook, T. L., Haltia-Hovi, E., Kukkonen, M., Lozhkin, A. V., Rosén, P., Tarasov, P. E., Vogel, H., and Wagner, B.: 2.8 Million Years of Arctic climate change from Lake El'gygytgyn, NE Russia, Science, 307, 315-310, doi:10.1126/science.1222135, 2012.

Monecke, K., Anselmetti, F. S., Becker, A., Sturm, M., and Giardini, D.: The record of historic earthquakes in lake sediments of Central Switzerland, Tectonophysics, 394, 21-40, 2004.

Monecke, K., Anselmetti, F. S., Becker, A., Schnellmann, M., Sturm, M., and Giardini, D.: Earthquake-induced deformation structures in lake deposits: A Late Pleistocene to Holocene paleoseismic record for Cental Switzerland, Eclogae. Geol. Helv., 99, 343-362, 2007.

Mulder, T. and Alexander, J.: The physical character of subaqueous sedimentary density flows and their deposits, Sedimentology, 48, 269-299, 2001.

Mulder, T. and Cochonat, P.: Classification of offshore mass movements, J. Sed. Res., 66, 43-57, 1996.

Mulder, T., Syvitski, J. P. M., Migeon, S., Faugeres, J.-C., and Savoye, B.: Marine hyperpycnal flows: initiation, behavios and related deposits, A review, Mar. Petrol. Geol., 20, 861-882, 2003.

Niessen, F., Gebhardt, A. C., Kopsch, C., and Wagner, B.: Seismic investigation of the El'gygytgyn impact crater lake Central Chukotka, NE Siberia: preliminary results, J. Paleolimnol., 37, 49-63, 2007.

Nolan, M. and Brigham-Grette, J.: Basic hydrology, limnology, and meteorology of modern Lake El'gygytgyn, Siberia, J. Paleolimnol., 37, 17-35, 2007.

Nowaczyk, N. R., Melles, M., and Minyuk, P.: A revised age model for core PG1351 from Lake El'gygytgyn, Chukotka, based on magnetic susceptibility variations correlated to Northern Hemisphere insolation variations, J. Paleolimnol., 37, 65-76, 2007.

Nowaczyk, N. R., Haltia, E. M., Ulbricht, D., Wennrich, V., Sauerbrey, M. A., Rosén, P., Vogel, H., Francke, A., Meyer-Jacob, C., Andreev, A. A., and Lozhkin, A. V.: Chronology of Lake El'gygytgyn sediments, Clim. Past Discuss., 9, 3061-3102, doi:10.5194/cpd-9-3061-2013, 2013.

Osleger, D. A., Heyvaert, A. C., Stoner, J. S., and Verosub, K. L.: Lacustrine turbidites as indicators of Holocene storminess and climate: Lake Tahoe, California and Nevada, J. Paleolimnol., 42, 103-122, 2009.

Raschke, U., Reimold, W. U., Zaag, P., Pittarello, L., and Koeberl, C.: Lithostratigraphy of the impactite and bedrock section in ICDP drill core D1c from the El'gygytgyn impact crater, Russia, Meteorit. Planet. Sci., 48, 1143-1159, doi:10.1111/maps.12072, 2013.

Rothwell, R. G., Reeder, M. S., Anastasakis, G., Stow, D. A. V., Thomson, J., and Kähler, G.: Low sea-level stand emplacement of megaturbidites in the western and eastern Mediterranean Sea, 
Sediment. Geol., 135, 75-88, 2000.

Schnellmann, M., Anselmetti, F. S., Becker, A., Sturm, M., and Giardini, D.: Mass movement-induced fold-and-thrust belt structures in unconsolidated sediments in Lake Lucerne Switzerland, Sedimentology, 52, 271-289, 2005.

Schnellmann, M., Anselmetti, F. S., Giardini, D., and McKenzie, J. A.: 15000 Years of mass- movement history in Lake Lucerne: implications for seismic and tsunami hazards, Eclogae. Geol. Helv., 99, 409-428, 2007.

Schwamborn, G., Fedorov, G., Schirrmeister, L., Meyer, H., and Hubberten, H.-W.: Periglacial sediment variations controlled by late Quaternary climate and lake level change at Elgygytgyn Crater, Artic Siberia, Boreas, 37, 55-65, 2008.

Schwamborn, G., Fedorov, G., Ostanin, N., Schirrmeister, L., Andreev, A., and the El'gygytgyn Scientific Party: Depositional dynamics in the El'gygytgyn Crater margin: implications for the $3.6 \mathrm{Ma}$ old sediment archive, Clim. Past, 8, 1897-1911, doi:10.5194/cp-8-1897-2012, 2012.

Shanahan, T. M., Overpeck, J. T., Wheeler, W., Beck, J. W., Pigati, J. S., Talbot, M. R., Scholz, C. A., Peck, J., and King, J. W.: Paleoclimatic variations in West Africa from a record of late Pleistocene and Holocene lake level stands of Lake Bosumtwi, Ghana, Palaeogeogr. Palaeocl., 242, 287-302, 2006.

Stone, D. B., Layer, P. W., and Raikevich, M. I.: Age and paleomagnetism of the Okhotsk-Chukotka Volcanic Belt (OCVB) near Lake El'gygytgyn, Chukotka, Russia, Stephan Mueller Spec. Publ. Ser., 4, 243-260, 2009.

St-Onge, G., Mulder, T., Piper, D. J. W., Hillaire-Marcel, C., and Stoner, J. S.: Earthquake and flood-induced turbidites in the Saguenay Fjord Quebec: a Holocene paleoseismicity record, Quaternary Sci. Rev., 23, 283-294, 2004.

St-Onge, G., Chapron, E., Mulsow, S., Salas, M., Viel, M., Debret, M., Foucher, A., Mulder, T., Winiarski, T., Desmet, M., Costa, P. J. M., Ghaleb, B., Jaouen, A., and Locat, J.: Comparison of earthquake-triggered turbidites from the Saguenay (Eastern Canada) and Reloncavi (Chilean margin) Fjords: Implications for paleoseismicity and sedimentology, Sediment. Geol., 243-244, 89-107, doi:10.1016/j.sedgeo.2011.11.003, 2012.

Strachan, L. J.: Flow transformations in slumps: a case study from the Waitemata Basin, New Zealand, Sedimentology, 55, 13111332, doi:10.1111/j.1365-3091.2007.00947.x, 2008.
Strasser, M., Anselmetti, F. S., Fäh, D., Giardini, D., and Schnellmann, M.: Magnitudes and source areas of large prehistoric northern Alpine earthquakes revealed by slope failures in lakes, Geology, 34, 1005-1008, 2006.

Sturm, M. and Matter, A.: Turbidites and varves in Lake Brienz Switzerland: deposition of clastic detritus by density currents, Spec. Publ. Int., 2, 147-168, 1978.

Talbot, M. R. and Delibrias, G.: A new late Pleistocene-Holocene water-level curve for Lake Bosumtwi, Ghana, Earth Planet. Sc. Lett., 47, 336-344, 1980.

Talling, P., Masson, D. G., Sumner, E. J., and Malgesini, G.: Subaqueous sediment density flows: depositional processes and deposit types, Sedimentology, 59, 1937-2003, doi:10.1111/j.13653091.2012.01353.x, 2012.

Twichell, D. C., Cross, V. A., Hanson, A. D., Buck, B. J., Zybala, J. G., and Rudin, M. J.: Seismic architecture and lithofacies of turbidites in Lake Mead Arizona and Nevada, USA, an analogue for topographically complex basins, J. Sed. Res., 75, 134-148, 2005.

Vogel, H., Meyer-Jacob, C., Melles, M., Brigham-Grette, J., Andreev, A. A., Wennrich, V., Tarasov, P. E., and Rosén, P.: Detailed insight into Arctic climatic variability during MIS 11c at Lake El'gygytgyn, NE Russia, Clim. Past, 9, 1467-1479, doi:10.5194/cp-9-1467-2013, 2013.

Waldmann, N., Anselmetti, F. S., Ariztegui, D., Austin Jr., J. A., Pirouz, M., Moy, C. M., and Dunbar, R.: Holocene masswasting events in Lago Fagnano, Tierra del Fuego (54 ${ }^{\circ} \mathrm{S}$ ): implications for paleoseismicity of the Magallanes-Fagnano transform fault, Basin Res., 23, 171-190, doi:10.1111/j.13652117.2010.00489.x, 2010.

Wennrich, V., Francke, A., Dehnert, A., Juschus, O., Leipe, T., Vogt, C., Brigham-Grette, J., Minyuk, P. S., Melles, M., and El'gygytgyn Science Party: Modern sedimentation patterns in Lake El'gygytgyn, NE Russia, derived from surface sediment and inlet streams samples, Clim. Past, 9, 135-148, doi:10.5194/cp-9-135-2013, 2013a.

Wennrich, V., Minyuk, P., Borkhodoev, V., Francke, A., Ritter, B., Nowaczyk, N., Haltia, E. M., Brigham-Grette, J., Melles, M., and El'gygytgyn Science Party: Pliocene and Pleistocene climate and environmental history of Lake El'gygytgyn/NE Russia based on high-resolution inorganic geochemistry data, Clim. Past Discuss., submitted, 2013b. 